\title{
Effect of Co-Contaminants Uranium and Nitrate on lodine Remediation
}

\section{September 2017}

JE Szecsody

BD Lee

AR Lawter

NP Qafoku

CT Resch

SR Baum

II Leavy

VL Freedman 


\title{
DISCLAIMER
}

This report was prepared as an account of work sponsored by an agency of the United States Government. Neither the United States Government nor any agency thereof, nor Battelle Memorial Institute, nor any of their employees, makes any warranty, express or implied, or assumes any legal liability or responsibility for the accuracy, completeness, or usefulness of any information, apparatus, product, or process disclosed, or represents that its use would not infringe privately owned rights. Reference herein to any specific commercial product, process, or service by trade name, trademark, manufacturer, or otherwise does not necessarily constitute or imply its endorsement, recommendation, or favoring by the United States Government or any agency thereof, or Battelle Memorial Institute. The views and opinions of authors expressed herein do not necessarily state or reflect those of the United States Government or any agency thereof.

\author{
PACIFIC NORTHWEST NATIONAL LABORATORY \\ operated by \\ BATTELLE \\ for the \\ UNITED STATES DEPARTMENT OF ENERGY \\ under Contract DE-AC05-76RL01830 \\ Printed in the United States of America \\ Available to DOE and DOE contractors from the \\ Office of Scientific and Technical Information, \\ P.O. Box 62, Oak Ridge, TN 37831-0062; \\ ph: (865) 576-8401 \\ fax: (865) 576-5728 \\ email: reports@adonis.osti.gov
}

Available to the public from the National Technical Information Service

5301 Shawnee Rd., Alexandria, VA 22312

ph: (800) 553-NTIS (6847)

email: orders@ntis.gov <http://www.ntis.gov/about/form.aspx>

Online ordering: http://www.ntis.gov

This document was printed on recycled paper. 
PNNL-26955

RPT-DVZ-AFRI-048 Rev 0.0

\title{
Effect of Co-Contaminants Uranium and Nitrate on lodine Remediation
}

\author{
JE Szecsody \\ BD Lee \\ AR Lawter \\ NP Qafoku \\ CT Resch \\ SR Baum \\ II Leavy \\ VL Freedman
}

September 2017

Prepared for

the U.S. Department of Energy

under Contract DE-AC05-76RL01830

Pacific Northwest National Laboratory

Richland, Washington 99354 


\section{Summary}

The objective of this study is to evaluate the significance of co-contaminants on the migration and transformation of iodine species in the Hanford subsurface environment. These impacts are relevant because remedies that target individual contaminants like iodine, may not only impact the fate and transport of other contaminants in the subsurface, but also inhibit the effectiveness of a targeted remedy. For example, iodine (as iodate) co-precipitates with calcite, and has been identified as a potential remedy because it immobilizes iodine. Since uranium also co-precipitates with calcite in field sediments, the presence of uranium may also inhibit iodine co-precipitation. Another potentially significant impact from co-existing contaminants is iodine and nitrate. The presence of nitrate has been shown to promote biogeochemical reduction of iodate to iodide, thereby increasing iodine species subsurface mobility (as iodide exhibits less sorption). Hence, this study reports on both laboratory batch and column experiments that investigated a) the change in iodate uptake mass and rate of uptake into precipitating calcite due to the presence of differing amounts of uranium, b) the amount of change of the iodate bio-reduction rate due to the presence of differing nitrate concentrations, and c) whether nitrite can reduce iodate in the presence of microbes and/or minerals acting as catalysts.

Batch experiments were conducted to quantify coupled uranium-iodate behaviors, where iodate and uranium were either incorporation into calcite, or adsorbed to the mineral surface. Results demonstrated that the presence of uranium did not influence iodate removal from solution. However, increasing iodate concentrations enhanced uranium removal. Moreover, results indicated that a significant amount of iodate would not be removed from solution if added post-calcite precipitation. Since this result differs from uranium behavior, and multiple studies have shown that uranium incorporates into calcite, this implies that iodine mass is mainly incorporated into a different surface phase than calcite.

Experiments that investigated the impact of nitrate concentrations on the iodate bio-reduction rate demonstrated that iodate occurred in eight different Hanford vadose zone and aquifer sediments under both anoxic and oxic geochemical conditions. Iodate reduction decreased two-fold in the presence of $8.4 \mathrm{mg} / \mathrm{L} \mathrm{O}_{2}$ or in the presence of $8.4 \mathrm{mg} / \mathrm{L} \mathrm{O}_{2}$, and $27 \mathrm{mg} / \mathrm{L}$ nitrate. For 1-D column experiments under high sediment/water conditions, the presence of nitrate did not increase the observed abiotic/biotic iodate reduction rate, implying that any increase in the co-metabolic bio-reduction rate of nitrate and iodate was a small contribution.

Separate experiments with a microbial isolate (Shewanella oneidensis, MR-1) or an enrichment culture with Ringold sediments were executed to evaluate the influence of nitrate on microbiallymediated iodate reduction. Sediments that were pretreated with $2 \%$ gluteraldehyde for 7 days to decrease microbial activity and resulted in a 9-fold decrease in the iodate reduction rate, implying some microbial contribution to the overall iodate reduction. Sediments that were pretreated with 5\% peroxide to oxidize reduced iron and manganese phases, and to decrease microbial activity, resulted in a 15-fold decrease in the iodate reduction rate. This result implies abiotic processes control most of the observed iodate reduction in the sediments at high sediment/water ratio found in the field. 


\section{Contents}

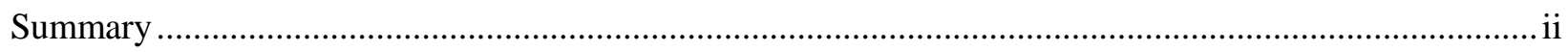

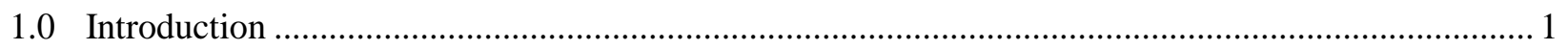

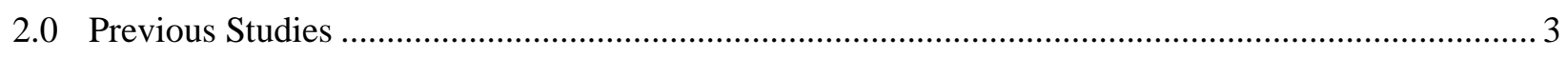

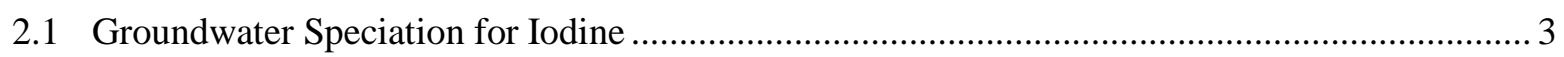

2.2 Iodine Species in Vadose Zone Cores .............................................................................. 4

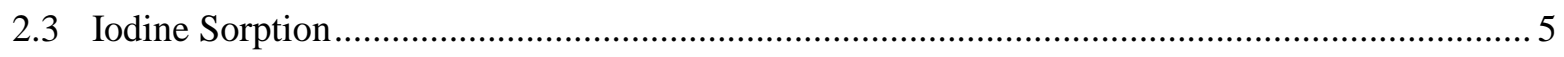

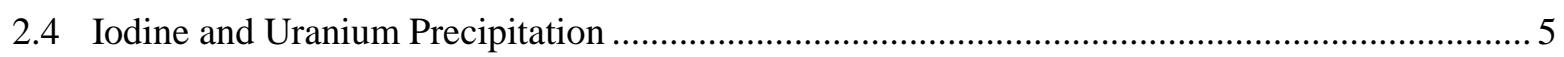

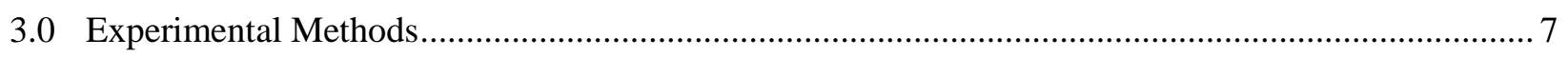

3.1 Iodine Speciation Reduction/Oxidation Experiments ........................................................... 7

3.2 Experiments of Iodine and Uranium Incorporation into Calcite During Precipitation ................ 8

3.3 Iodine and Nitrate Biotransformation Experiments ............................................................ 9

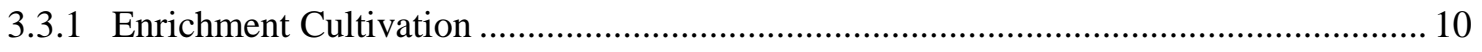

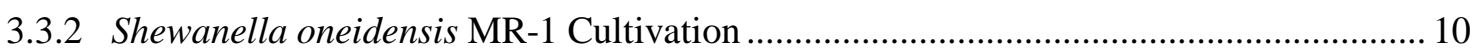

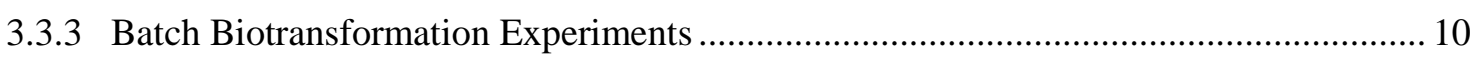

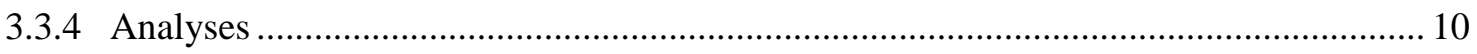

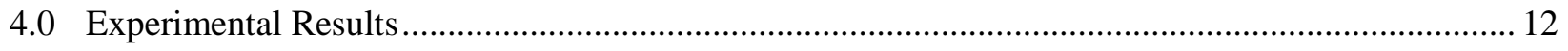

4.1 Iodine Species Redox Reactivity with Sediments .............................................................. 12

4.1.1 Coupled Iodate and Nitrate Reduction ..................................................................... 12

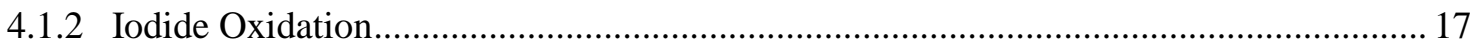

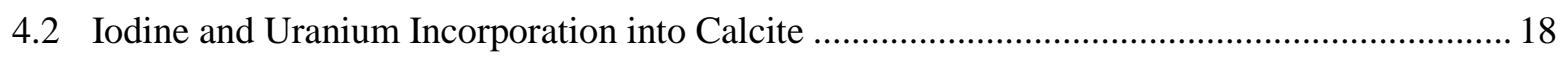

4.3 Iodine Species Microbial Reactivity in the Presence of Nitrate.............................................. 23

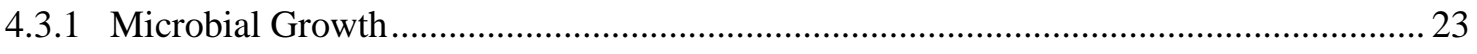

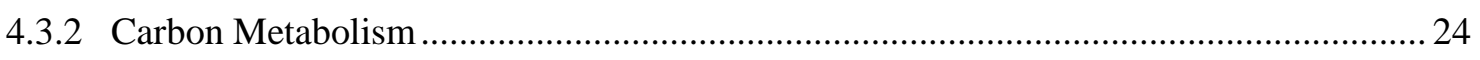

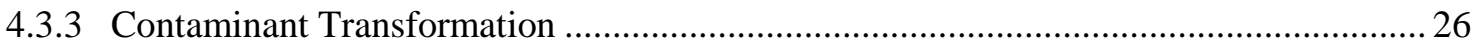

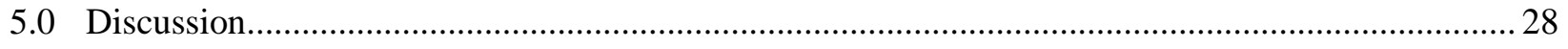

5.1 Iodine Species-Sediment Interactions with Co-Contaminants .............................................. 28

5.1.1 Influence of Co-Contaminants on Iodate Reduction in Sediments ................................28

5.1.2 Influence of Nitrate on Iodide Oxidation in Sediments................................................. 29

5.2 Iodine Species Co-precipitation in Calcite with Co-contaminants.......................................... 30

5.3 Iodine Species Redox Behavior with Mainly Microbial Isolates and Co-contaminants ............ 30

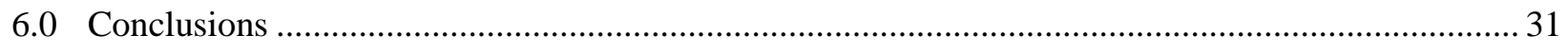

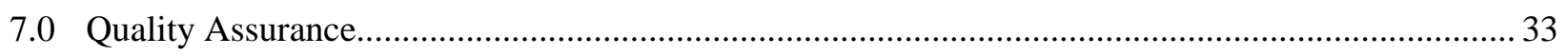

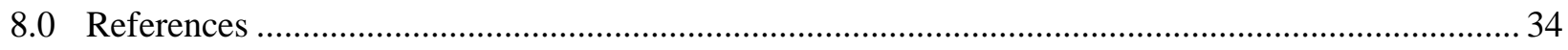




\section{Figures}

Figure 1. Aqueous stability under different $\mathrm{pH}$ and redox conditions for iodine species (left) and nitrogen species (right) (Research Center for Deep Geological Environments 2005)..................................... 2

Figure 2. Plume map of I-129 contamination in the Hanford 200 Area (Lee et al. 2017)....................... 4

Figure 3. Correlation of leached mass and rate in 1-D columns from vadose zone cores (B-, T-, and SComplex) and aquifer cores (UP-1) for a) I-127 and b) U-238. (Data from Szecsody et al. 2017; Truex et al. 2017).

Figure 4. Iodate reduction (abiotic/biotic) in 1-D stop-flow columns with C9483, 387-388' aquifer sediment at a) different sediment/water ratio; b) oxic water with $\mathrm{NO}_{3}$; c) anaerobic water with $\mathrm{NO}_{3}$; d) oxic water with $\mathrm{NO}_{3}$ (and high sediment/water ratio); e) anaerobic no $\mathrm{NO}_{3}, \mathrm{f}$ ) anaerobic, no $\mathrm{NO}_{3}$, 2\% gluteraldehyde treatment; and g) anaerobic, no $\mathrm{NO}_{3}$, peroxide treatment. (Data from Truex et al.

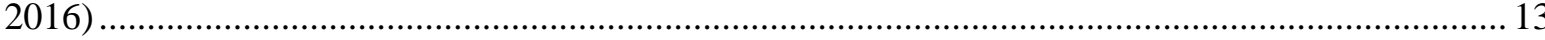

Figure 5. Iodate reduction (abiotic/biotic) in contact with different vadose zone sediments in 1-D stopflow columns: a) E31, b) E32, c) E33, d) E34, e) E35, f) E37, g) E35, and h) E38 (data from Szecsody et al. 2017). Borehole and depth written on each figure.

Figure 6. Coupled iodate and reduction (abiotic/biotic) in contact with four different aquifer sediments in 1-D stop-flow columns, showing nitrate and nitrite in experiments: a) E132, b) E133, c) E135, and d) E136. Borehole and depth written on each figure.

Figure 7. Coupled iodate and reduction (abiotic/biotic) in contact with UP-1 aquifer sediments in 1-D stop-flow columns, showing I-127 in experiments: a) E132, b) E133, c) E135, and d) E136. Borehole and depth written on each figure.

Figure 8. Coupled iodate and reduction (abiotic/biotic) in contact with vadose zone sediments showing: a) $\mathrm{N}$-species during 20 pore volume injection of $0.1 \mathrm{mg} / \mathrm{L}$ nitrate, b) $\mathrm{N}$-species during 20 pore volume injection of $1.0 \mathrm{mg} / \mathrm{L}$ nitrate and $1.0 \mathrm{mg} / \mathrm{L}$ nitrite, c) $\mathrm{N}$-species transformation over time initially with only nitrate, and d) $\mathrm{N}$-species transformation over time initially with nitrate and nitrite.

Figure 9. Iodide stability in sediments with a) oxic water, low sediment/water ratio; b) anaerobic water, low sediment/water ratio; c) oxic water, high sediment/water ratio; d) oxic water, high sediment/water ratio with $2 \%$ gluteraldehyde (and sediment pretreatment); and e) oxic water with peroxide pretreatment of the sediment. (Data from Truex et al. 2016)

Figure 10. Iodine (A and B) and uranium (C and D) concentrations over time in calcite precipitation batch experiments with variable initial I and U concentrations: A) initial I concentrations of $50 \mathrm{ppb}$; B) initial I concentrations of $500 \mathrm{ppb}$; C) initial U concentrations of $100 \mathrm{ppb}$; D) initial U concentrations of $1000 \mathrm{ppb}$. The legend in each graph indicates concentrations of both I and $\mathrm{U}$ in parenthesis next to each test ID.

Figure 11. U (top) and I (bottom) concentrations for the "late spike" tests. Spikes that were added late (i.e., after calcite precipitation) are indicated in the legend......

Figure 12. Comparison between tests with $1000 \mathrm{ppb} \mathrm{U}$ initial concentrations; one was spiked prior to calcite precipitation (circles) and one was spiked after precipitation (late spike, diamonds).

Figure 13. Protein concentration in microcosms studies over time: A) S. oneidensis MR-1 without sediment; B) S. oneidensis MR-1 with sediment; C) Hanford enrichment without sediment; D) Hanford enrichment with sediment. (Note: S. oneidensis timescale is hours, while enrichment is in days.)...

Figure 14. Lactate metabolism in microcosm experiments in which S. oneidensis MR-1 was tested for iodate and nitrate biotransformation: A) lactate concentration without sediment, B) acetate 
concentration without sediment; C) lactate concentration with sediment; D) acetate concentration with sediment

Figure 15. Lactate metabolism in microcosm experiments in which a Hanford enrichment culture was tested for iodate and nitrate biotransformation: A) lactate concentration without sediment; B) acetate concentration without sediment; C) lactate concentration with sediment; D) acetate concentration with sediment................................................................................................................. 26

Figure 16. Nitrate transformation in microcosm experiments: A) S. oneidensis with Ringold sediments;

B) Hanford enrichment culture with Ringold sediments. ............................................................... 27 


\section{Tables}

Table 1. Iodine species sorption and transformation experiments with sediments.................................. 8

Table 2. Test matrix from the U/I calcite incorporation experiments. The U and I spike concentrations and time of addition varied. Some experiments were conducted for 28 days while others had a 60-

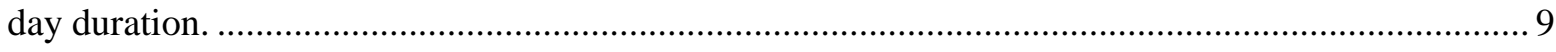

Table 3. Experimental matrix for biotransformation microcosm studies. ${ }^{(a)}$............................................ 11

Table 4. Maximum leached iodate and nitrate concentrations in UP-1 cores........................................ 15

Table 5. Final U and I concentrations associated with the calcite solid, in $\mu \mathrm{g} / \mathrm{g}$ for Tests 1-3................. 20

Table 6. Iodate and nitrate reduction rates measured in sediments......................................................... 28

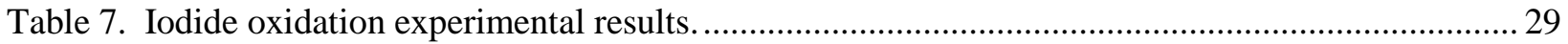




\subsection{Introduction}

The objective of this co-mingled study is to evaluate the significance of co-contaminants on the migration and transformation of iodine species in the Hanford subsurface environment. Prediction of iodine and iodate movement in the subsurface has evolved over the past few years as additional information has become available on speciation, abiotic, and biotic transformation reactions. For example, although iodide $\left(\mathrm{I}^{-}\right)$and iodate $\left(\mathrm{IO}_{3}{ }^{-}\right)$are the two aqueous species in nearly all of the Hanford subsurface (i.e., $\mathrm{I}_{2}(\mathrm{aq})$ exists under $\mathrm{pH}<1$ conditions; $\mathrm{I}_{2} \mathrm{OH}^{-}$exists at $\mathrm{pH} 1$ to 7 ; Figure $1 \mathrm{a}$ ), significant iodine mass is partitioning to the sediment phases by a) anionic sorption; b) incorporation into carbonate, iron oxide, and other mineral phases; or c) being complexed with natural organic matter, which may be aqueous or sorbed to sediments.

Prediction of iodine species movement in the subsurface depends on quantifying these processes. Other contaminants (i.e., uranium, nitrate, technetium, chromium, and cyanide) may interact with iodine species directly or with sediment mineral phases or microbial populations. It is likely that some of the interactions between contaminants may influence mobility of the contaminants at field scale. For example, iodate can be slowly reduced to iodide by the in situ microbial consortium associated with sediments, but this bioreduction occurs more rapidly in the presence of nitrate, which is typically present at a higher concentration. In addition, while iodine (as iodate) has been identified as incorporating into calcite in field sediments, uranium also incorporates into calcite, so when both iodate and uranium are present, the amount of incorporation of each may decrease. Finally, it is possible that nitrate could reduce iodate (Figure 1) with an inorganic catalyst or microbially.

To address these co-contaminant issues, a panel of Pacific Northwest National Laboratory geochemists, microbiologists, and modelers met several times to identify a) all possible co-contaminant interactions, and b) priority co-contaminant interactions that are likely relevant in the Hanford Site 200 Area, based on significant plume overlap and contaminant concentrations. Two co-contaminant issues were identified as having the highest priority and potential significance at field scale: a) influence of iodate uptake mass and rate by the presence of uranium, and b) influence of the iodate bioreduction rate in the presence of nitrate. One additional co-contaminant issue was investigated related to the iodine-nitrate system: redox cycling between iodine and nitrogen species. Therefore, the objectives of this study were to

- determine how much the iodate bioreduction rate changes due to the presence of differing nitrate concentrations,

- identify the change in iodate uptake mass and rate of uptake into precipitating calcite due to the presence of differing amounts of uranium, and

- evaluate whether iodide oxidation to iodate can reduce nitrate in the presence of microbes and/or minerals acting as catalysts, since iodide can reduce nitrite to NO under acidic conditions. 

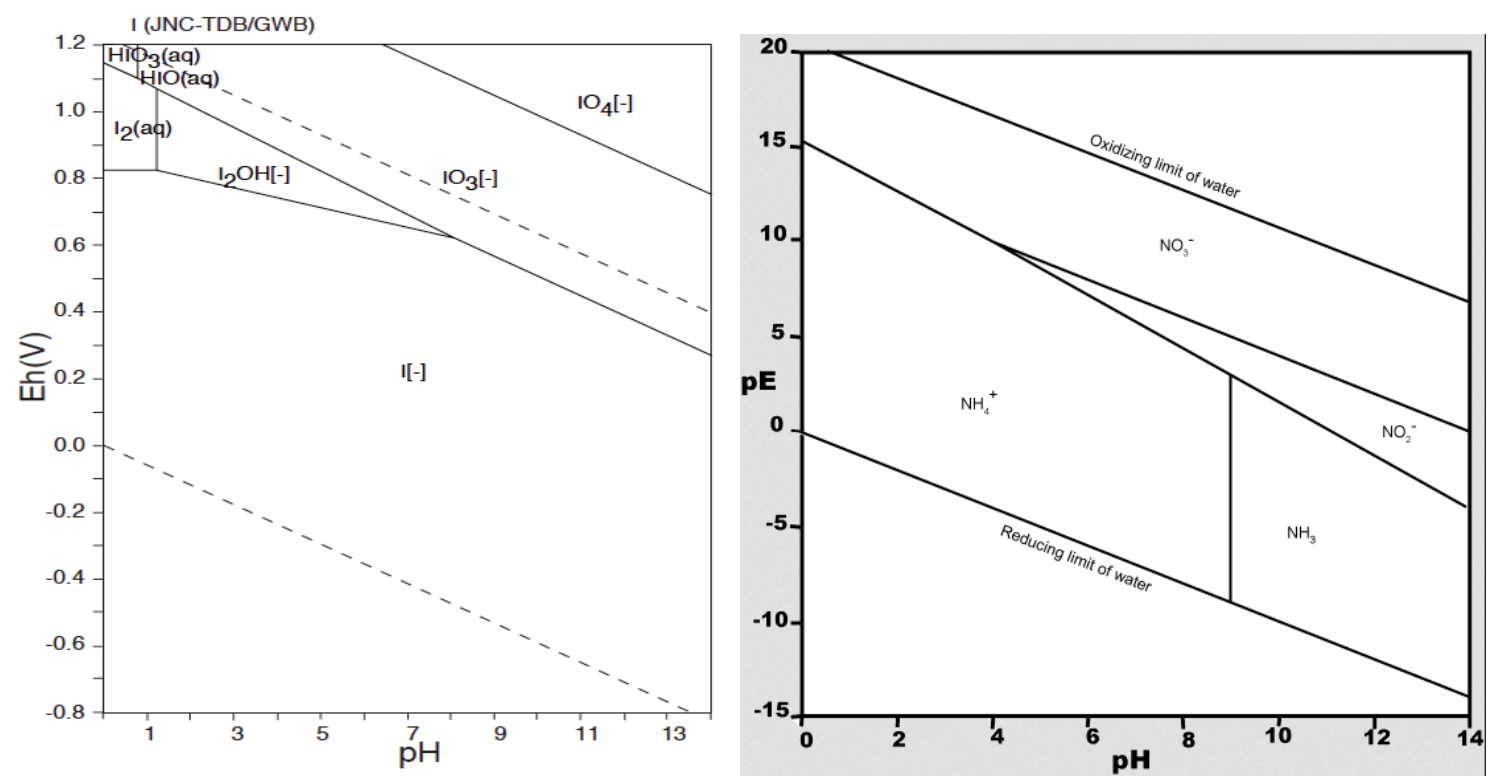

Figure 1. Aqueous stability under different $\mathrm{pH}$ and redox conditions for iodine species (left) and nitrogen species (right) (Research Center for Deep Geological Environments 2005).

Because these processes are applied to the subsurface environment, iodine species adsorption and reduction/oxidation in the presence of sediments with or without viable microbial populations are also reported. Results of these laboratory experiments are used to fill existing gaps in conceptual site models and to provide data to predict contaminant transport rates in regions of overlapping plumes. 


\subsection{Previous Studies}

Iodine exists in different states in the subsurface, including different isotopes, different speciation, and in different phases. Predominant isotopic compositions are I-127 and I-129, whereas only the latter is radioactive. Subsurface fate and transport of iodine is also largely dependent on its chemical speciation, as iodine can be present in both aqueous and solid phases. Unlike most aqueous species, iodine in its reduced form as iodide, is more mobile than when it is in its oxidized form as iodate. The data presented in this section report on both speciation and isotopic composition and are from analyses presented in Lee et al. (2017 ${ }^{1}$; this data is presented for information only). These data are summarized here because they provide context for the co-mingled contaminant impacts presented in this report for the vadose zone and the groundwater.

\subsection{Groundwater Speciation for lodine}

Hanford 200 Area wells sampled in 2016 were analyzed for both I-127 and I-129 (Lee et al., 2017'; this data is presented for information only) for the area shown in Figure 2. Total iodine and iodine speciation were measured, and demonstrate that the fraction of I-129 within the total iodine measured is very small $\left(\sim 10^{-3}-10^{-5} \mu \mathrm{g} / \mathrm{L}\right)$. Although speciation measurements were only recorded for $\mathrm{I}-127$, these results demonstrated that iodate was the predominant species. Only one groundwater sample, located just beneath the water table, showed a significant presence of iodide (45\%). This result is consistent with the assumption that the original contamination was released as iodide. These results also suggest a process occurs in the aquifer (or during sampling) that oxidizes iodide to iodate.

\footnotetext{
${ }^{1}$ Lee BD, JE Szecsody, NP Qafoku, EM McElroy, SR Baum, MM Snyder, AR Lawter, MJ Truex, BN Gartman, L Zhong, DL Saunders, BD Williams, JA Horner, II Leavy, CT Resch, BB Christiansen, RE Clayton, and KC Johnson. 2017. Contaminant Attenuation and Transport Characterization of 200-UP-1 Operable Unit Sediment Samples. RPT-DVZ-CHPRC-0001, Pacific Northwest National Laboratory, Richland, WA. This data is presented for information only, as Lee et al (2017) has not been release for use at the time this report was written.
} 


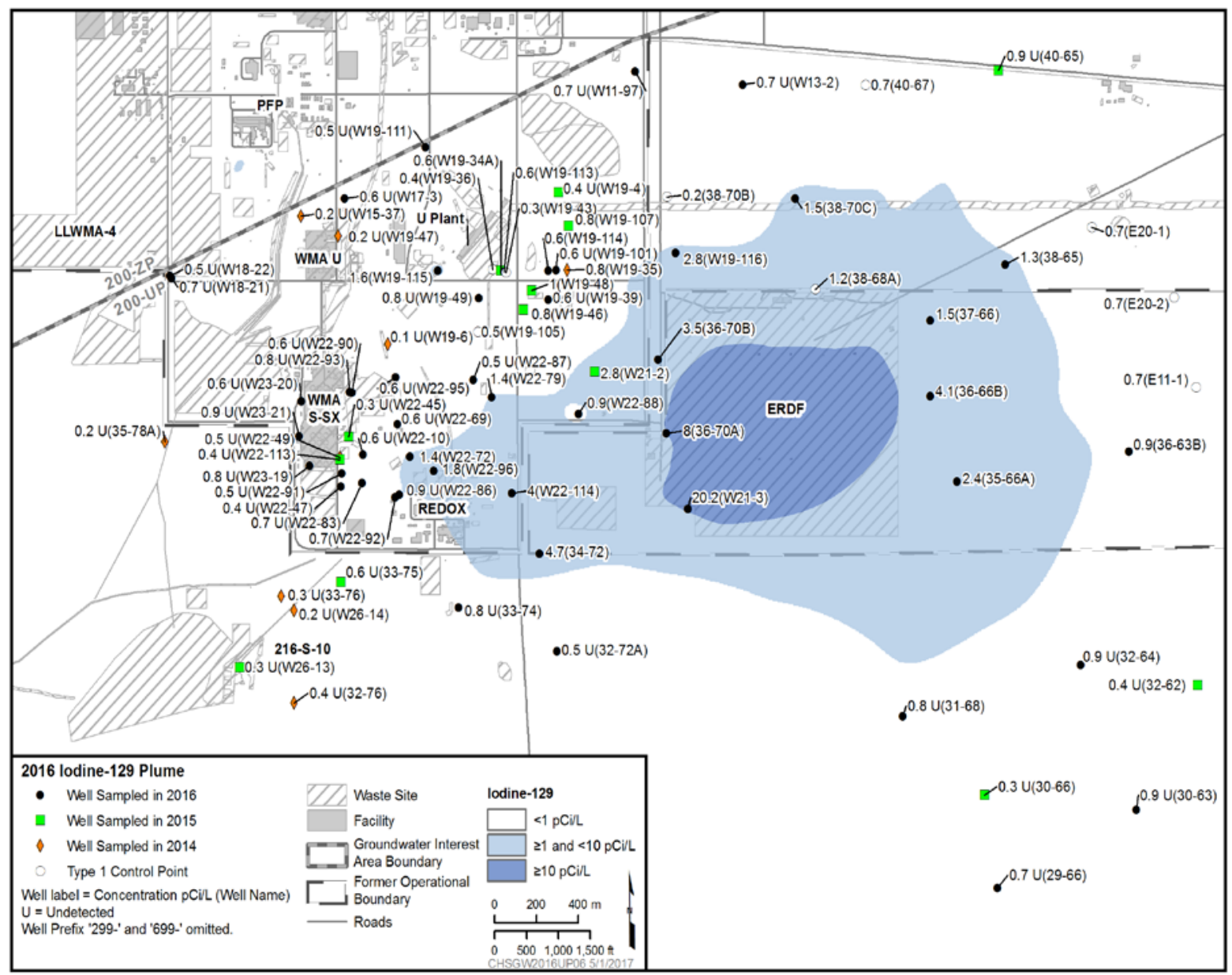

Figure 2. Plume map of I-129 contamination in the Hanford 200 Area (Lee et al. 2017¹).

\section{2 lodine Species in Vadose Zone Cores}

Vadose zone cores collected beneath the B-, T-, and S-Complexes showed significantly different concentration trends than in the groundwater (Truex et al. 2017a; Szecsody et al. 2017). Whereas groundwater was predominated by iodate, iodine aqueous concentrations were predominated by iodide in the unsaturated zones. In both batch and core leaching experiments, iodide predominated. In batch experiments, three cores were iodide-dominated and one core had about equal mass fractions. Batch experiments for all cores showed a slow release of the total I-127 from sediments over hundreds of hours, implying an initial rapid release of adsorbed iodine, followed by a slow release of iodate from the dissolution of calcite. For core leaching experiments, iodide was the dominant species in five cores, and iodate predominated in two cores (and one with equal leached iodide and iodate mass). In most cases, iodide leached sooner from the sediment compared to iodate, which is consistent with less iodide sorption to sediments (Section 4.1). 


\subsection{Iodine Sorption}

Early studies of iodide sorption have reported distribution coefficients $\left(\mathrm{K}_{\mathrm{d}}\right)$ with values in the range of 0 to $2 \mathrm{~mL} / \mathrm{g}$ (Kaplan et al. 2000). More recently, studies in Hanford sediments have identified species specific sorption as 0.3 to $1.2 \mathrm{~mL} / \mathrm{g}$ (retardation factor of 2.4 to 6.2 ), and iodide sorption as 0.07 to $0.1 \mathrm{~mL} / \mathrm{g}$ (retardation factor 1.3 to 1.5) (Truex et al. 2016). Both of these measurements were made in the presence of $30 \mathrm{mg} / \mathrm{L}$ nitrate, although the presence of $30 \mathrm{mg} / \mathrm{L}$ nitrate did not appear to change iodate sorption (i.e., as a competing anion, it should decrease iodate sorption). Sorption has also identified as being related to organic carbon content. Clays such as illite adsorb iodine more strongly, with $\mathrm{K}_{\mathrm{d}}$ values as high as $28 \mathrm{~mL} / \mathrm{g}$ (Kaplan et al. 2000).

\section{4 lodine and Uranium Precipitation}

If iodine and uranium are both incorporated into calcite, and calcite is slowly dissolving during leaching, then similar iodine and uranium release rate trends would be observed for each core. However, this was not observed in Szecsody et al. 2017, Truex et al. 2017a, and Lee et al. 2017, as cores that leached the most iodine were not correlated with cores that leached the most uranium. The most striking difference between iodine and uranium leaching behavior was that the uranium exhibited no differences between vadose zone and aquifer cores (Figure 3). By contrast, aquifer cores generally leached less iodine (and at a slower rate) than vadose zone cores. This difference in leaching behavior between iodine and uranium implies that they are leaching from different surface phases (e.g., sorption vs. mineral phase). Since multiple studies have shown that uranium incorporates into calcite (Zachara et al. 2007a; b, Qafoku and Icenhower 2008; Catalano et al. 2008), this may indicate that iodine is held differently in calcite or mainly in a different mineral phase (such as iron oxides). 


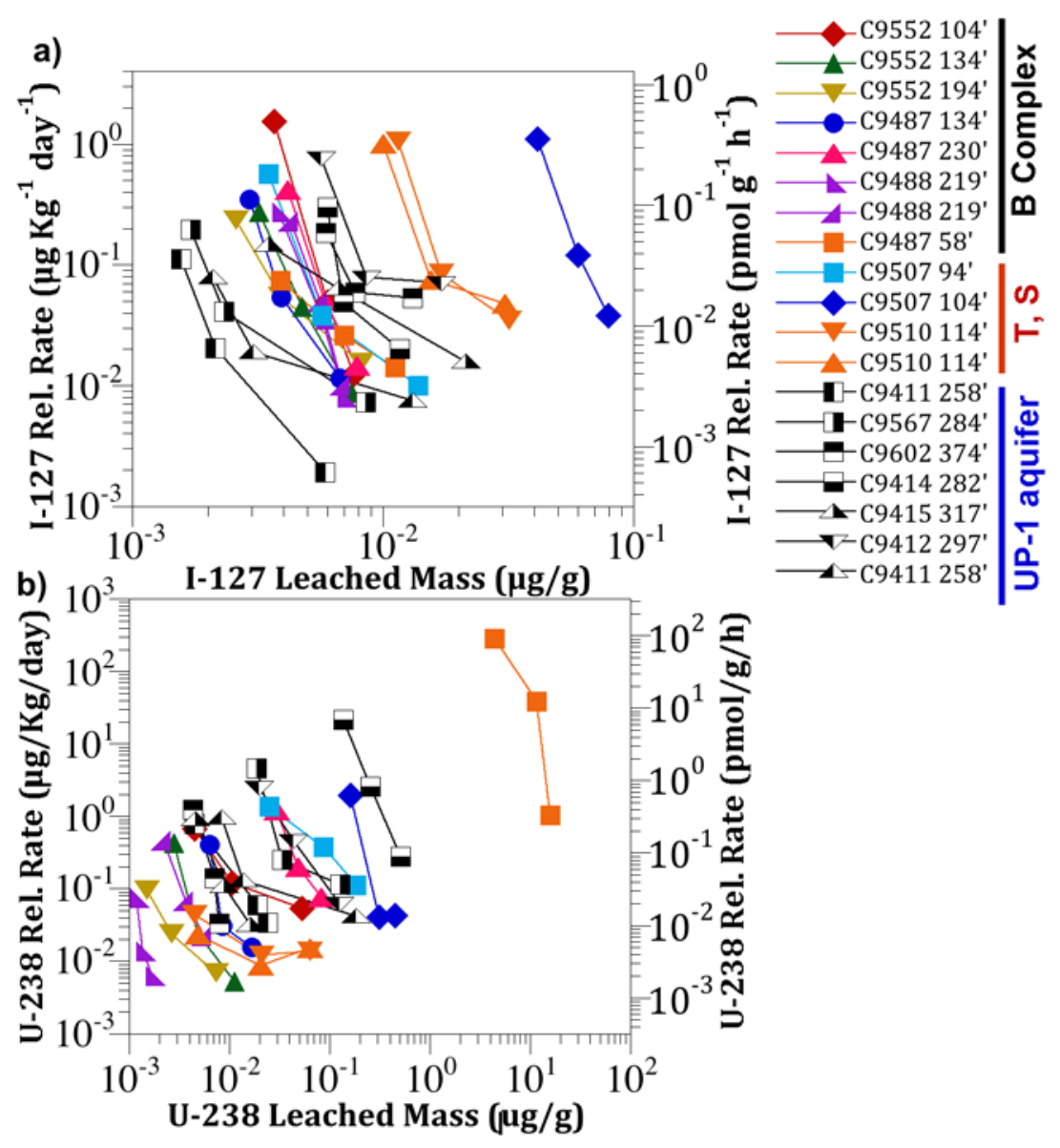

Figure 3. Correlation of leached mass and rate in 1-D columns from vadose zone cores (B-, T-, and SComplex) and aquifer cores (UP-1) for a) I-127 and b) U-238. (Data from Szecsody et al. 2017; Truex et al. 2017a) 


\subsection{Experimental Methods}

\subsection{Iodine Speciation Reduction/Oxidation Experiments}

Sediments used in this study include two 200 Area aquifer sediments: C9483, 387-388' and C9412 295.4-295.9'. Iodate reduction (Section 4.1.1) and iodide oxidation experiments (Section 4.1.2) were conducted with these sediments, without and with the presence of co-contaminants nitrate and uranium. Experiments D26 to D31 and E132 to E136 are experiments conducted in this study (Table 2), whereas experiments D2 to D16 were from a previous study (Truex et al. 2016) that supported the current study.

Iodide and iodate sorption experiments were conducted in a) batch vials at different sediment/water ratios, and b) 1-D columns by characterizing iodine species retardation. Batch experiments consisted of mixing iodide or iodate (at $100 \mu \mathrm{g} / \mathrm{L}$ ) in artificial groundwater at sediment/water ratios from 0.05 to $1.3 \mathrm{~g} / \mathrm{mL}$ for 48 hours, then measuring the remaining iodine species in aqueous solution. This standard method was effective for iodide, but not for iodate, due to iodate reduction during the experiment time scale. Iodide and iodate sorption was then measured in 1-D columns packed with sediment and pre-equilibrated with artificial groundwater. Effluent samples taken during the injection of $100 \mu \mathrm{g} / \mathrm{L}$ iodide or iodate were used to characterize the retardation of iodine species due to sorption. Column experiments were conducted without nitrate and with $27 \mathrm{mg} / \mathrm{L}$ nitrate to compare the effect on iodine species sorption (and reduction). The 1-D column injection experiments were conducted at a flow rate of 8.0 pore volumes per hour, so that 20 pore volumes could be injected within 3 hours, thus minimizing the effect of iodate reduction on breakthrough. A second method was used to calculate the amount of iodate sorption in sediment columns using data during the 2000-hour reduction portion of the experiment (i.e., after the initial injection phase). By 2000 hours, nearly all iodate was converted to iodide, which has a lower sorption capacity. Therefore, the final aqueous iodide concentration (in $\mu \mathrm{mol} / \mathrm{L}$ at 2000 hours) was used as the total initial iodate concentration. The difference between the total initial iodate concentration and the iodate breakthrough concentration (equal to the injection solution concentration) was the sorbed iodate concentration. The $\mathrm{K}_{\mathrm{d}}$ value was then calculated from the sorbed iodate concentration (in $\mu \mathrm{mol} / \mathrm{g}$ ) divided by the aqueous iodate concentration (in $\mu \mathrm{mol} / \mathrm{mL}$ ).

Iodide oxidation experiments were conducted in 1-D stop-flow columns at a sediment/water ratio of $5 \mathrm{~g} / \mathrm{mL}$ in artificial groundwater with $100 \mu \mathrm{g} / \mathrm{L}$ iodide, without and with dissolved oxygen, and with $27 \mathrm{mg} / \mathrm{L}$ nitrate (Table 1). One experiment was also conducted with $2 \%$ gluteraldehyde pretreatment of the sediment for 7 days, then 2\% gluteraldehyde during the 2000-hour experiment to kill the microbial population (Table 1, D10). Another experiment was conducted with pretreatment of the sediment with $5 \%$ peroxide to oxidize ferrous iron phases (Table 1, D13). Iodate reduction experiments were conducted in 1-D stop-flow columns at a sediment/water ratio of $5 \mathrm{~g} / \mathrm{mL}$ in artificial groundwater with $100 \mu \mathrm{g} / \mathrm{L}$ iodate, without and with dissolved oxygen, and without and with $27 \mathrm{mg} / \mathrm{L}$ nitrate. One experiment was also conducted with $2 \%$ gluteraldehyde pretreatment of the sediment for 7 days, then $2 \%$ gluteraldehyde during the 2000-hour experiment (Table 1, D11). Another experiment was conducted with pretreatment of the sediment with $5 \%$ peroxide (Table 1, D15). 
Redox cycling experiments with one core (C9412 295.4-295.9') involved three stop-flow column experiments and three solution stability (i.e., no sediment) experiments (Table 1, experiments D26, 27 and 28). The three stop-flow column experiments involved the 20 pore volume injection of a) $150 \mu \mathrm{g} / \mathrm{L}$ iodate and $150 \mu \mathrm{g} / \mathrm{L}$ iodide; b) $150 \mu \mathrm{g} / \mathrm{L}$ iodate, $150 \mu \mathrm{g} / \mathrm{L}$ iodide, and $1.0 \mathrm{mg} / \mathrm{L}$ nitrate; and c) $150 \mu \mathrm{g} / \mathrm{L}$ iodate, $150 \mu \mathrm{g} / \mathrm{L}$ iodide, $1.0 \mathrm{mg} / \mathrm{L}$ nitrate, and $1.0 \mathrm{mg} / \mathrm{L}$ nitrite into a sediment column. Three separate batch experiments contained only these three solutions to confirm aqueous stability in contact with no microbes or mineral surfaces (Table 1, D29-D31).

Table 1. Iodine species sorption and transformation experiments with sediments.

\begin{tabular}{|c|c|c|c|c|c|c|c|}
\hline $\begin{array}{c}\text { exp. } \\
\#\end{array}$ & sediment & $\begin{array}{l}\text { sed. } \\
\text { (g) }\end{array}$ & $\begin{array}{l}\text { iodate } \\
\text { (ug/L) }\end{array}$ & $\begin{array}{l}\text { iodide } \\
\text { (ug/L) }\end{array}$ & $\begin{array}{l}\text { nitrate } \\
(\mathrm{mg} / \mathrm{L})\end{array}$ & $\begin{array}{c}O_{2} \\
(\mathrm{mg} / \mathrm{L})\end{array}$ & other \\
\hline D2 & C9483, 387-388' & 33 & 0 & 50 & 0 & 8.4 & \\
\hline D3 & C9483, 387-388' & 10 & 100 & 27 & 27 & 8.4 & \\
\hline D4 & C9483, 387-388' & 120 & 0 & 100 & 27 & 8.4 & \\
\hline D5 & C9483, 387-388' & 120 & 0 & 100 & 27 & 0.0 & \\
\hline D6 & C9483, 387-388' & 35 & 100 & 27 & 27 & 8.4 & \\
\hline D7 & C9483, 387-388' & 35 & 100 & 27 & 27 & 0.0 & \\
\hline D8 & C9483, 387-388' & 350 & 100 & 27 & 27 & 8.4 & \\
\hline D9 & C9483, 387-388' & 366 & 0 & 100 & 27 & 8.4 & \\
\hline D10 & C9483, 387-388' & 358 & 0 & 100 & 27 & 8.4 & $2 \%$ gluteraldehyde \\
\hline D11 & C9483, 387-388' & 355 & 100 & 27 & 27 & 0.0 & $2 \%$ gluteraldehyde \\
\hline D12 & none & 0 & 0 & 100 & 0.0 & 8.4 & \\
\hline D13 & C9483, 387-388' & 10 & 0 & 100 & 0.0 & 8.4 & $5 \% \mathrm{H}_{2} \mathrm{O}_{2}$ \\
\hline D14 & none & 0 & 100 & 0 & 0.0 & 0.0 & \\
\hline D15 & C9483, 387-388' & 10 & 100 & 0.0 & 0.0 & 0.0 & $5 \% \mathrm{H}_{2} \mathrm{O}_{2}$ \\
\hline D16 & C9483, 387-388' & 334 & 100 & 0.0 & 0.0 & 0.0 & \\
\hline D26 & C9412, 295.4-296 & 339 & 150 & 150 & 0.0 & 8.4 & \\
\hline D27 & C9412, 295.4-296 & 396 & 150 & 150 & 0.1 & 8.4 & \\
\hline D28 & C9412, 295.4-296 & 371 & 150 & 150 & 1.0 & 8.4 & $1.0 \mathrm{mg} / \mathrm{L}$ nitrite \\
\hline D29 & none & 0 & 150 & 150 & 0.0 & 8.4 & \\
\hline D30 & none & 0 & 150 & 150 & 0.1 & 8.4 & \\
\hline D31 & none & 0 & 150 & 150 & 1.0 & 8.4 & $1.0 \mathrm{mg} / \mathrm{L}$ nitrite \\
\hline E132 & C9567 284-285' & 454 & 150 & 0 & 9.93 & 1.05 & \\
\hline E133 & C9602 376-377' & 417 & 150 & 0 & 20.1 & 1.78 & \\
\hline E135 & C9415 317-318' & 419 & 150 & 0 & 0.90 & & \\
\hline E136 & C9412 296-297' & 392 & 150 & 0 & 19.4 & & \\
\hline
\end{tabular}

\subsection{Experiments of lodine and Uranium Incorporation into Calcite During Precipitation}

A series of four batch experiments were conducted to determine extent of incorporation of $U$ and I (as iodate) into calcite when present as co-contaminants. The batch experiments are listed in Table 2.

Experiments used no sediments.

To precipitate calcite, $100 \mathrm{~mL}$ of $0.1 \mathrm{M} \mathrm{CaCl}_{2}$ solution was added to a $250-\mathrm{mL}$ poly bottle on a stir plate with slow stirring. The iodine and uranium spikes were then added to the $\mathrm{CaCl}_{2}$ solution followed by addition of $100 \mathrm{~mL}$ of $0.1 \mathrm{M}\left(\mathrm{NH}_{4}\right)_{2} \mathrm{CO}_{3}$. The iodine and uranium concentrations varied; see Table 2 for the concentration ranges and time of spikes. This mixing resulted in almost instantaneous precipitation of calcium carbonate. For Test 4, the $U$ and I spikes were not all added prior to calcite precipitation. Spike addition varied, and was either done prior to calcite precipitation, as in Tests 1-3, or 
1 day after calcite precipitation started. The "late spike” tests are conducted to determine if the U and/or I is being incorporated into the calcite structure (in which case, it would not be removed when spiked "late"), or if it is being adsorbed onto the surface of the calcite (in which case, there should be little to no difference between experiments spiked prior to and after calcite precipitation).

Each of the experiments was conducted in duplicate, and included two solution blanks: one containing the $0.1 \mathrm{M} \mathrm{CaCl}_{2}$ with the $\mathrm{U}$ and/or I spikes, and one containing the $\left(\mathrm{NH}_{4}\right)_{2} \mathrm{CO}_{3}$ with the $\mathrm{U}$ and/or I spikes. The $\mathrm{pH}$ was measured at the beginning of each test. To sample, $2 \mathrm{~mL}$ of supernatant was removed from each test bottle at approximately 0, 4, and 24 hours, and 4, 7, 14, 21, and 28 days. Some experiments were continued for a total of 60 days, as indicated in Table 2. For the 60-day experiments, additional samples were taken at 42 and 60 days. The Test 4 "late spike" experiments had additional samples taken prior to the delayed spike, but follow the same general sampling schedule after these preliminary sampling times. The 2-mL sample was filtered with a $0.2-\mu \mathrm{m}$ syringe filter and submitted for $\mathrm{U}$ and I analysis via inductively coupled plasma-mass spectrometry (ICP-MS). The $\mathrm{pH}$ of each bottle was measured immediately following each sampling event, and the contents of the bottles were swirled gently after the $\mathrm{pH}$ measurement was completed.

Table 2. Test matrix from the U/I calcite incorporation experiments. The $U$ and I spike concentrations and time of addition varied. Some experiments were conducted for 28 days while others had a 60-day duration.

\begin{tabular}{|c|c|c|c|c|}
\hline Test number & $\begin{array}{c}\text { Spiked } \\
\text { concentrations } \\
\text { of } U \\
\text { (ppb) }\end{array}$ & $\begin{array}{c}\text { Spiked } \\
\text { concentrations } \\
\text { of iodine } \\
\text { (as } \mathrm{IO}_{3}, \mathrm{ppb} \text { ) }\end{array}$ & Time of $U$ and I spike addition & $\begin{array}{c}\text { Duration of } \\
\text { experiments } \\
\text { (days) }\end{array}$ \\
\hline Test 1 (A-B) & 0 & 0 & start of test & 28 \\
\hline Test 1 (C-F) & 0 & 50 & start of test & 28 \\
\hline Test 1 (G-J) & 0 & 500 & start of test & 60 \\
\hline Test 2 (A-D) & 100 & 0 & start of test & 28 \\
\hline Test 2 (E-H) & 100 & 50 & start of test & 28 \\
\hline Test 2 (I-L) & 100 & 500 & start of test & 60 \\
\hline Test 3 (A-D) & 1000 & 0 & start of test & 60 \\
\hline Test 3 (E-H) & 1000 & 50 & start of test & 60 \\
\hline Test $3(I-L)$ & 1000 & 500 & start of test & 60 \\
\hline Test 4 (A-D) & 1000 & 0 & start of test & 60 \\
\hline Test 4 (E-H) & 1000 & 500 & U and I late spike & 60 \\
\hline Test 4 (I-L) & 1000 & 500 & U late spike (I spiked at start of test) & 60 \\
\hline Test 4 (M-P) & 1000 & 500 & I late spike (U spiked at start of test) & 60 \\
\hline
\end{tabular}

\subsection{Iodine and Nitrate Biotransformation Experiments}

Batch microcosm experiments were performed using a Shewanella isolate known to reduce iodate and nitrate, as well as a mixed community that had been enriched from Hanford sediments taken from cores from boreholes in the 200-UP-1 operable unit. These experiments are designed to determine the effect of nitrate on iodate reduction, since nitrate is present in groundwater in part-per-million concentrations, while iodine is present in part-per-billion concentrations. 


\subsubsection{Enrichment Cultivation}

Enrichment was performed using sediment from core C9482, interval B31F57 from I-129 hydraulic containment wells in the 200-UP-1 operable unit. Approximately $1 \mathrm{~g}$ of sediment was added to a $125-\mathrm{mL}$ serum bottle with $50 \mathrm{~mL}$ M9 minimal media $\left(\left(\mathrm{NH}_{4}\right)_{2} \mathrm{SO}_{4}(1.0 \mathrm{~g}), \mathrm{NaCl}(5.0 \mathrm{~g}), \mathrm{MgSO}_{4} * 7 \mathrm{H}_{2} \mathrm{O}(0.2 \mathrm{~g})\right.$, yeast extract ( $0.5 \mathrm{~g})$; $\mathrm{pH}$ to 7.5$)$. Enrichments were conducted under microaerobic conditions, spiked with $100 \mu \mathrm{g} / \mathrm{L}$ potassium iodate and $20 \mathrm{mg} / \mathrm{L}$ sodium nitrate to promote growth of iodate/nitrate reducing bacteria. Sodium lactate (10 mM) was included as the carbon and electron source for growth and contaminant reduction. Enrichments were sparged with $\mathrm{N}_{2}$ for 10 minutes before placing on a tabletop shaker (125 rpm) at room temperature. Cell density was determined using 4,6-diamidino-2-phenylindole (DAPI) once bacterial solution became turbid. The initial cell density was $1 \times 10^{7}$ cells $/ \mathrm{mL}$ in batch microcosms.

\subsubsection{Shewanella oneidensis MR-1 Cultivation}

Shewanella oneidensis (MR-1) was used in batch experiments due to its diverse ability to reduce metals as well as reduce nontraditional electron acceptors, such as iodate. Previously isolated MR-1 was treated under the same conditions as the enrichment culture; however, unlike the enrichment, MR-1 is a fast-growing bacterium with typical exponential phase lasting approximately 6 hours. As with the enrichment, DAPI analysis was conducted to obtain an initial cell density of $1 \times 10^{7}$ cells $/ \mathrm{mL}$.

\subsubsection{Batch Biotransformation Experiments}

A series of batch experiments were prepared by adding $10 \mathrm{~mL}$ M9 media into 20 -mL serum vials. Amendment type and concentration is dependent on the batch being performed (see Table 3). Samples were spiked with $20 \mathrm{mg} / \mathrm{L}$ nitrate and/or $100 \mu \mathrm{g} / \mathrm{L}$ iodate. The Ringold Formation sediment used was from a core in borehole C9411 at 258 to 259'. Batches that contained MR-1 were sampled approximately every 6 and 12 hours for a total of 48 hours, while those that contained the microbial community were sampled every other day for approximately 9 days. Samples were incubated at room temperature, and shaken at $125 \mathrm{rpm}$. Tests were set up for destructive sampling. Sampling consisted of taking $1 \mathrm{~mL}$ of solution for total protein analysis. The remainder was centrifuged at 10,000 xg for 15 minutes. Supernatant was extracted and filtered through a $0.22-\mu \mathrm{m}$ filter. Supernate was analyzed for ferrous iron, total iodine, iodine speciation, and nitrate (Section 3.3.4.2).

\subsubsection{Analyses}

\subsubsection{Total Protein Analysis}

Cell density in the microcosms was monitored using the bicinchoninic acid (BCA) protein assay, since turbidity in flasks with sediment would preclude determination with a spectrophotometer. Two milliliters of each culture was pelleted at $7500 \mathrm{xg}$ for 15 minutes, the supernatant decanted and cell pellets were frozen at $-80^{\circ} \mathrm{C}$ until the assay was performed. Cells were lysed by adding $0.5 \mathrm{~mL}$ of B-PER reagent to the pellet and incubated for 5 minutes at room temperature. Following incubation, the mixture was centrifuged at $15,000 \mathrm{xg}$ for 5 minutes, supernatant collected, and boiled on a hot block at $100^{\circ} \mathrm{C}$ for 10 minutes. Once cooled on ice and brought to room temperature, $25 \mu \mathrm{L}$ of each sample was added to 
$200-\mu \mathrm{L}$ BCA working reagent in a 96 well plate (followed BCA assay protocol), incubated at $37^{\circ} \mathrm{C}$ for 30 minutes, and read on a spectrophotometer at a wavelength of $562 \mathrm{~nm}$.

\subsubsection{Inorganic Species Analysis}

The ferrozine assay was used to measure ferrous iron $\left(\mathrm{Fe}^{2+}\right)$ concentration from the reduction of ferric iron $\left(\mathrm{Fe}^{3+}\right)$ in samples that contained Ringold sediment. Briefly; $100 \mu$ ferrozine solutions $(1 \mathrm{~g} / \mathrm{L}$ ferrozine in $500 \mathrm{~g} / \mathrm{L}$ ammonium acetate) was added to the preserved samples. Samples were allowed to incubate for 30 minutes, at room temperature, before reading on a spectrophotometer at $562 \mathrm{~nm}$. Nitrate and nitrite were analyzed by ion chromatography. Iodine species (iodate and iodide) were analyzed by an ICP-MS for a) total I-127 (iodide plus iodate), and b) iodine species. Iodine species analysis involved using an ion chromatography column to separate iodine species before mass spectrometry analysis.

Table 3. Experimental matrix for biotransformation microcosm studies. ${ }^{(a)}$

\begin{tabular}{|c|c|c|c|c|c|c|c|}
\hline & $\begin{array}{c}\text { Media } \\
\text { (mineral } \\
\text { salts) } \\
\text { [negative } \\
\text { control] }\end{array}$ & $\begin{array}{c}\text { Media + } \\
1 \mathrm{O}_{3} \\
\text { (ug/L) } \\
\text { [negative } \\
\text { control] }\end{array}$ & $\begin{array}{c}\text { Media + } \\
\mathrm{NO}_{3} \\
\text { (mg/L) } \\
\text { [negative } \\
\text { control] }\end{array}$ & $\begin{array}{c}\text { Media + } \\
\mathrm{IO}_{3} \\
+\mathrm{NO}_{3} \\
\text { [negative } \\
\text { control] }\end{array}$ & $\begin{array}{c}\text { Media + } \mathrm{IO}_{3} \\
\text { + Bacteria }\end{array}$ & $\begin{array}{c}\text { Media + } \\
\mathrm{NO}_{3} \\
+ \text { Bacteria }\end{array}$ & $\begin{array}{c}\text { Media }+\mathrm{IO}_{3} \\
+\mathrm{NO}_{3} \\
+ \text { Bacteria }\end{array}$ \\
\hline MR-1 & 0 & 100 & 20 & $100 / 20$ & 100 & 20 & $100 / 20$ \\
\hline MR-1 & & & & & 100 & 20 & $100 / 20$ \\
\hline MR-1 & & & & & 100 & 20 & $100 / 20$ \\
\hline MR-1 + Ringold sediment & 0 & 100 & 20 & $100 / 20$ & 100 & 20 & $100 / 20$ \\
\hline MR-1 + Ringold sediment & & & & & 100 & 20 & $100 / 20$ \\
\hline MR-1 + Ringold sediment & & & & & 100 & 20 & $100 / 20$ \\
\hline Enrich & 0 & 100 & 20 & $100 / 20$ & 100 & 20 & $100 / 20$ \\
\hline Enrich & & & & & 100 & 20 & $100 / 20$ \\
\hline Enrich & & & & & 100 & 20 & $100 / 20$ \\
\hline Enrich + Ringold sediment & 0 & 100 & 20 & $100 / 20$ & 100 & 20 & $100 / 20$ \\
\hline MR-1 + Ringold sediment & & & & & 100 & 20 & $100 / 20$ \\
\hline MR-1 + Ringold sediment & & & & & 100 & 20 & $100 / 20$ \\
\hline
\end{tabular}

(a) Values listed in the table are iodate concentration ( $\mu \mathrm{g} / \mathrm{L}$ ) and nitrate concentration (mg/L). For example, 100/20 represents $100 \mu \mathrm{g} / \mathrm{L}$ iodate and $20 \mathrm{mg} / \mathrm{L}$ nitrate. 


\subsection{Experimental Results}

\section{1 lodine Species Redox Reactivity with Sediments}

The iodine species aqueous stability shows that under highly oxidizing conditions and $\mathrm{pH}>7$, iodate is the dominant anion, whereas under slightly reducing conditions, iodide should form. Under acidic $(1<$ $\mathrm{pH}<7$ ) and slightly reducing conditions, $\mathrm{I}_{2} \mathrm{OH}^{-}$should form, but under more reducing conditions, iodide should form (Figure 1a). Experiments were conducted to investigate the coupled abiotic/biotic iodide oxidation and iodate reduction under relevant Hanford groundwater conditions (i.e., $\mathrm{pH}$ 8, varying amount of dissolved oxygen), without and with nitrate and nitrite co-contaminants.

\subsubsection{Coupled lodate and Nitrate Reduction}

Iodate reduction was measured under different geochemical conditions to evaluate the rate of reduction and additionally quantify the significance of abiotic or microbial reduction. An initial batch reduction experiment showed a more rapid rate of iodate reduction at a higher sediment/water ratio (all points at 46.3 hours), which implies that mineral phases or adsorbed microbes (or both) are promoting iodate reduction. The artificial groundwater in this experiment contained $27 \mathrm{mg} / \mathrm{L}$ nitrate. The reduction rate normalized for the variable mass of sediment was $2.70 \pm 0.99 \mathrm{pmol} \mathrm{h}^{-1} \mathrm{~g}^{-1}$ (Figure $4 \mathrm{a}$ ). Long-term (i.e., 1800-hour) experiments conducted with sediments indicate that the iodate reduction rate with no oxygen (i.e., anaerobic) and no nitrate was $13.2 \mathrm{pmol} \mathrm{h}^{-1} \mathrm{~g}^{-1}$ (Figure 4e). With the addition of $27 \mathrm{mg} / \mathrm{L}$ nitrate (still anaerobic), the iodate reduction rate decreased to $4.95 \mathrm{pmol} \mathrm{h}^{-1} \mathrm{~g}^{-1}$ (Figure 4c). With the addition of $8.4 \mathrm{mg} / \mathrm{L}$ oxygen (oxygen-saturated water) and $27 \mathrm{mg} / \mathrm{L}$ nitrate, the reduction rate was 3.64 to $7.08 \mathrm{pmol} \mathrm{h}^{-1} \mathrm{~g}^{-1}(10 \mathrm{~b}, \mathrm{~d})$. These results indicate that in sediments, excess nitrate did not increase the iodate reduction rate, and in fact decreased it slightly. The presence of dissolved oxygen in water did not change the iodate reduction rate.

To evaluate the microbial contribution to iodate reduction, a sediment column was treated with $2 \%$ gluteraldehyde for 7 days before iodate (with nitrate-containing artificial groundwater) injection (Figure 4f), which had an iodate reduction rate $\left(1.47 \mathrm{pmol} \mathrm{h}^{-1} \mathrm{~g}^{-1}\right)$ that was 3.4 times slower than with no gluteraldehyde treatment (Figure 4c, $4.95 \mathrm{pmol} \mathrm{h}^{-1} \mathrm{~g}^{-1}$ ). Therefore, while a decrease in the microbial population had some influence, it appears that the majority of the iodate reduction in this sediment was abiotically controlled.

To evaluate the role of reduced mineral phases (i.e., adsorbed $\mathrm{Fe}^{2+}, \mathrm{Mn}^{2+}$ or $\mathrm{Fe}^{2+}, \mathrm{Mn}^{2+}$ in clay minerals), a sediment was treated with a strong oxidant (peroxide) for 4 days, then the peroxide was washed out of the sediment (although some peroxide may have remained). This should have the effect of oxidizing many of the oxidizable phases. The iodate reduction in this experiment appeared significantly slower (Figure 4g), with a half-life of 1060 hours, but there was only a small amount of sediment in the experiment (10 g), so the reduction rate $\left(0.887 \mathrm{pmol} \mathrm{h}^{-1} \mathrm{~g}^{-1}\right)$ was 15 times slower than it was with no peroxide treatment Figure 4e, $13.2 \mathrm{pmol} \mathrm{h}^{-1} \mathrm{~g}^{-1}$ ). These results appear to show that abiotic phases have the most significant influence on the iodate reduction rate. 

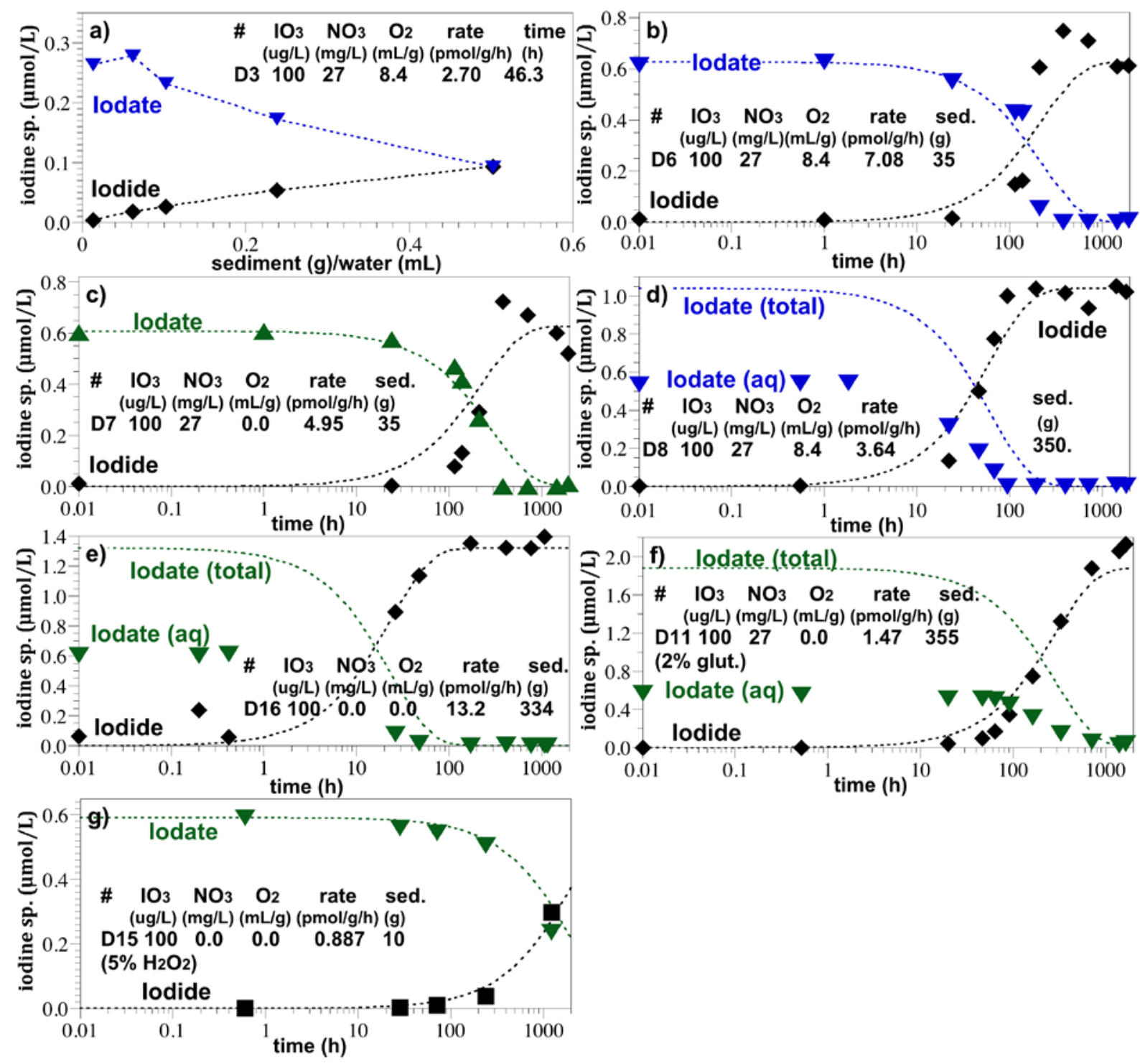

Figure 4. Iodate reduction (abiotic/biotic) in 1-D stop-flow columns with C9483, 387-388' aquifer sediment at a) different sediment/water ratio; b) oxic water with $\mathrm{NO}_{3}$; c) anaerobic water with $\mathrm{NO}_{3}$; d) oxic water with $\mathrm{NO}_{3}$ (and high sediment/water ratio); e) anaerobic no $\mathrm{NO}_{3}$, f) anaerobic, no $\mathrm{NO}_{3}, 2 \%$ gluteraldehyde treatment; and g) anaerobic, no $\mathrm{NO}_{3}$, peroxide treatment. (Data from Truex et al. 2016)

It should be noted that results of this one 200 Area aquifer sediment (C9483, 387-388'), which reduced iodate in most experiments, appear counter to field results that indicate iodine species in groundwater is mainly (85\% average) iodate (Xu et al. 2015). Several hypotheses could account for this difference, including 1) collection of aquifer water in the field is oxidizing iodide (by sunlight or other mechanism), 2) repacking sediment into 1-D columns or batch systems exposes fresh Fe(II) surfaces that enhance abiotic reduction (i.e., experimental artifact), and 3) coupled abiotic/biotic iodate reduction varies significantly in field sediments. 
The first hypothesis could be addressed by a simple experiment exposing aqueous iodide to sunlight. The third hypothesis is addressed by evaluating the iodate reduction in different sediments. Seven noflow 1-D column experiments were conducted with six DV-1 vadose zone sediments (Figure 5) in which the aqueous solution added initially contained $100 \mu \mathrm{g} / \mathrm{L}$ iodate (Szecsody et al. 2017). These sediments all had iodate reduction rates, which varied about two orders of magnitude from 0.06 to $12 \mathrm{pmol} \mathrm{h}^{-1} \mathrm{~g}^{-1}$ (i.e., similar in magnitude to C9483 387' sediment in Figure 5). These results imply (but do not prove) that iodate reduction occurs naturally, and in the DV-1 sediments roughly correlated with microbial biomass. If repacking the sediments into columns enhanced abiotic reduction by exposing fresh Fe(II) surfaces (hypothesis 2), then the effect should be nearly the same in all sediments, as the mass of $\mathrm{Fe}(\mathrm{II}) / \mathrm{Fe}(\mathrm{III})$ phases in the sediments were similar (Szecsody et al. 2017). The same generalization could be made that if ex situ microbial contamination caused most of the effect, the effect should be similar in different sediments (which was not observed). Iodate and nitrate reduction in four UP-1 sediments (Figure 6 and Figure 7) show significant differences in rates between sediments.
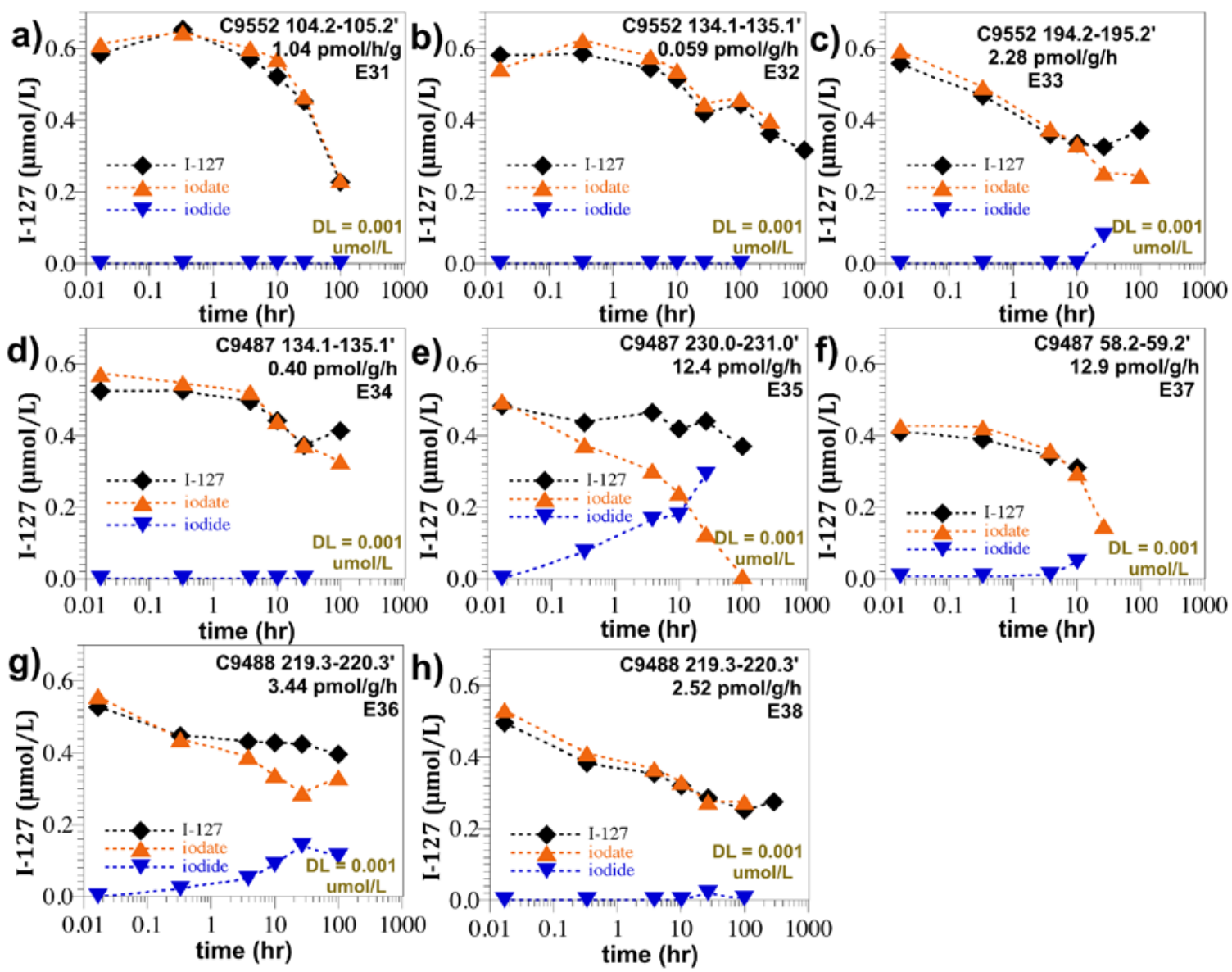

Figure 5. Iodate reduction (abiotic/biotic) in contact with different vadose zone sediments in 1-D stopflow columns: a) E31, b) E32, c) E33, d) E34, e) E35, f) E37, g) E35, and h) E38 (data from Szecsody et al. 2017). Borehole and depth written on each figure.

Removal of sediment and packing into experimental systems can expose fresh mineral surfaces, which could increase observed reduction rates (i.e., experimental artifact is causing the observed iodate reduction). This hypothesis can be addressed by experiments with undisturbed sediment (i.e., use a field 
core), but the edges of the core are still disturbed. Another method to address this hypothesis is to compare batch studies (with continuous mixing or grinding of sediment in a vial) to 1-D column studies, where sediment was disturbed only during packing. Seven batch experiments were conducted with six DV-1 vadose zone sediments in which no additional iodine was added, but there was slow release of iodine over hundreds of hours, likely due to carbonate or Fe-oxide dissolution (Szecsody et al. 2017). These experiments were continuously mixed (12 rpm) for 1000 hours, and thus should have caused significantly more mechanical disturbance to the particles compared to 1-D column experiments in which the sediment was only disturbed during packing. In four of the batch experiments, there was sufficient iodine in the sediment to measure iodine speciation and one that did show that the $\sim 1 \mu \mathrm{g} / \mathrm{L}$ mainly iodate $(0.01 \mu \mathrm{mol} / \mathrm{L})$ appeared to be reduced to iodide around 20 to 50 hours (rate $1.02 \mathrm{pmol} / \mathrm{g} / \mathrm{h}$ ). The iodide concentration then decreased at later times (to 1000 hours), but the total iodine and iodate increased. However, this data appears to indicate that this hypothesis is not correct (i.e., particle breakup in batch systems does not cause more rapid iodate reduction compared with unmixed 1-D columns).

Experiments are underway with four 200 Area aquifer sediments that initially had 0.9 to $19.4 \mathrm{mg} / \mathrm{L}$ nitrate and 6.8 to $19.7 \mu \mathrm{g} / \mathrm{L}$ iodate contamination (Table 4 ). A total of 10 pore volumes of artificial groundwater containing $150 \mu \mathrm{g} / \mathrm{L}$ iodate and $300 \mu \mathrm{g} / \mathrm{L}$ nitrate was injected into sediment columns to evaluate the coupled nitrate and iodate reduction rates. Analysis of nitrate and nitrate for three of the sediments showed a decrease in nitrate, but nitrite concentration were generally below detection limits. In addition, for three of the sediments, nitrate increased, likely from the release of additional nitrate from the sediment (dissolution of a solid phase or diffusion from dead-end pores). Nitrate reduction rates calculated for three of the cores (1.35 to $20.3 \mathrm{pmol} / \mathrm{g} / \mathrm{h}$, Figure 6$)$ were similar in magnitude to rates for iodate reduction in different cores (Figure 5). The I-127 data (Figure 7) also shows iodate reduction in all four cores, with a significant increase in aqueous I-127, which is caused by the increased iodide (which sorbs less).
Table 4. Maximum leached iodate and nitrate concentrations in UP-1 cores.

\begin{tabular}{ccccc} 
& & & \multicolumn{2}{c}{ peak leached } \\
iodate & $\begin{array}{c}\text { nitrate } \\
\text { \# }\end{array}$ & sediment & (ug/L) & (mg/L) \\
\hline E132 & C9567 284-285' & 7.8 & 9.93 \\
E133 & C9602 & $376-377^{\prime}$ & 14 & 20.1 \\
E135 & C9415 & $317-318^{\prime}$ & 6.8 & 0.90 \\
E136 & C9412 296-297' & 19.7 & 19.4 \\
\hline
\end{tabular}



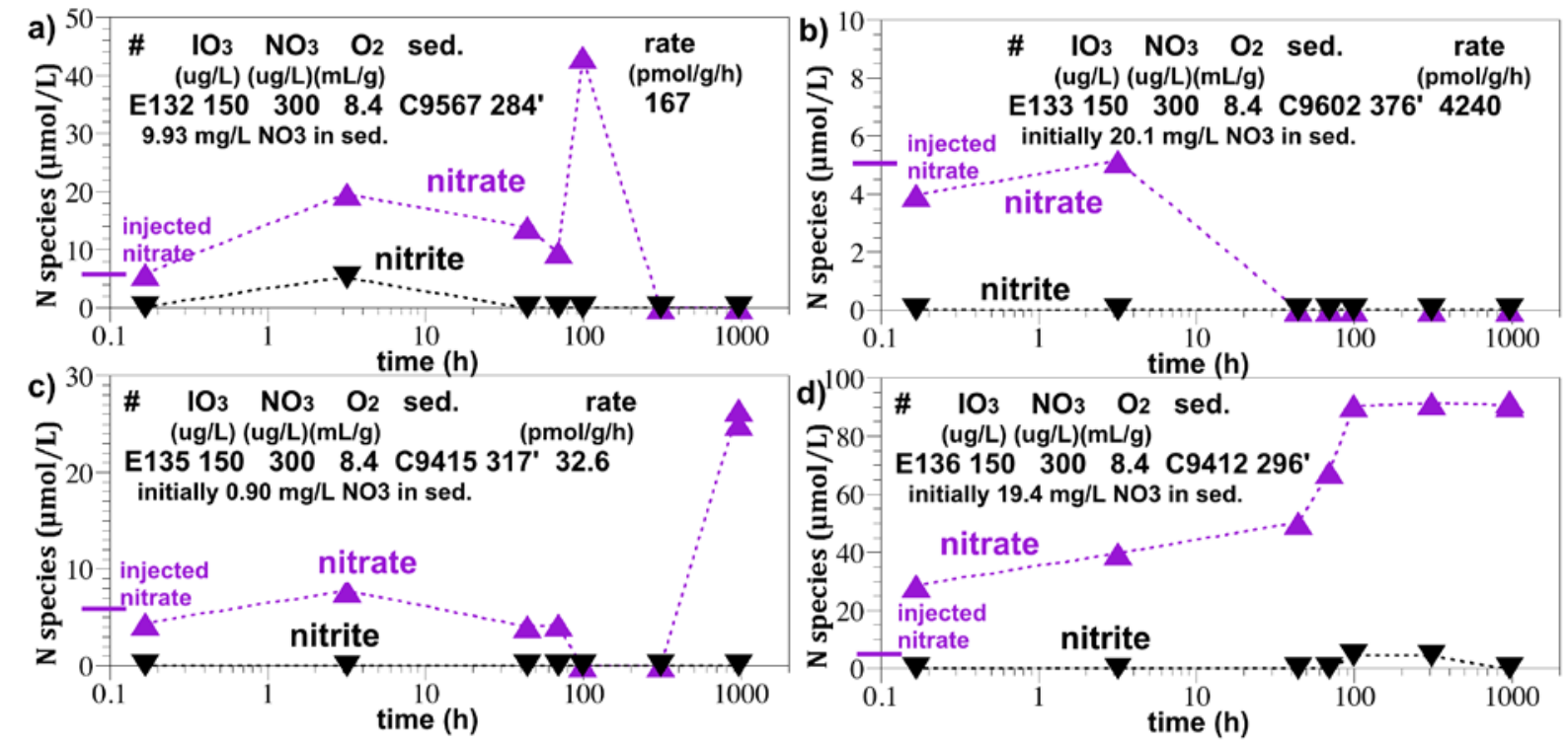

Figure 6. Coupled iodate and reduction (abiotic/biotic) in contact with four different aquifer sediments in 1-D stop-flow columns, showing nitrate and nitrite in experiments: a) E132, b) E133, c) E135, and d) E136. Borehole and depth written on each figure.
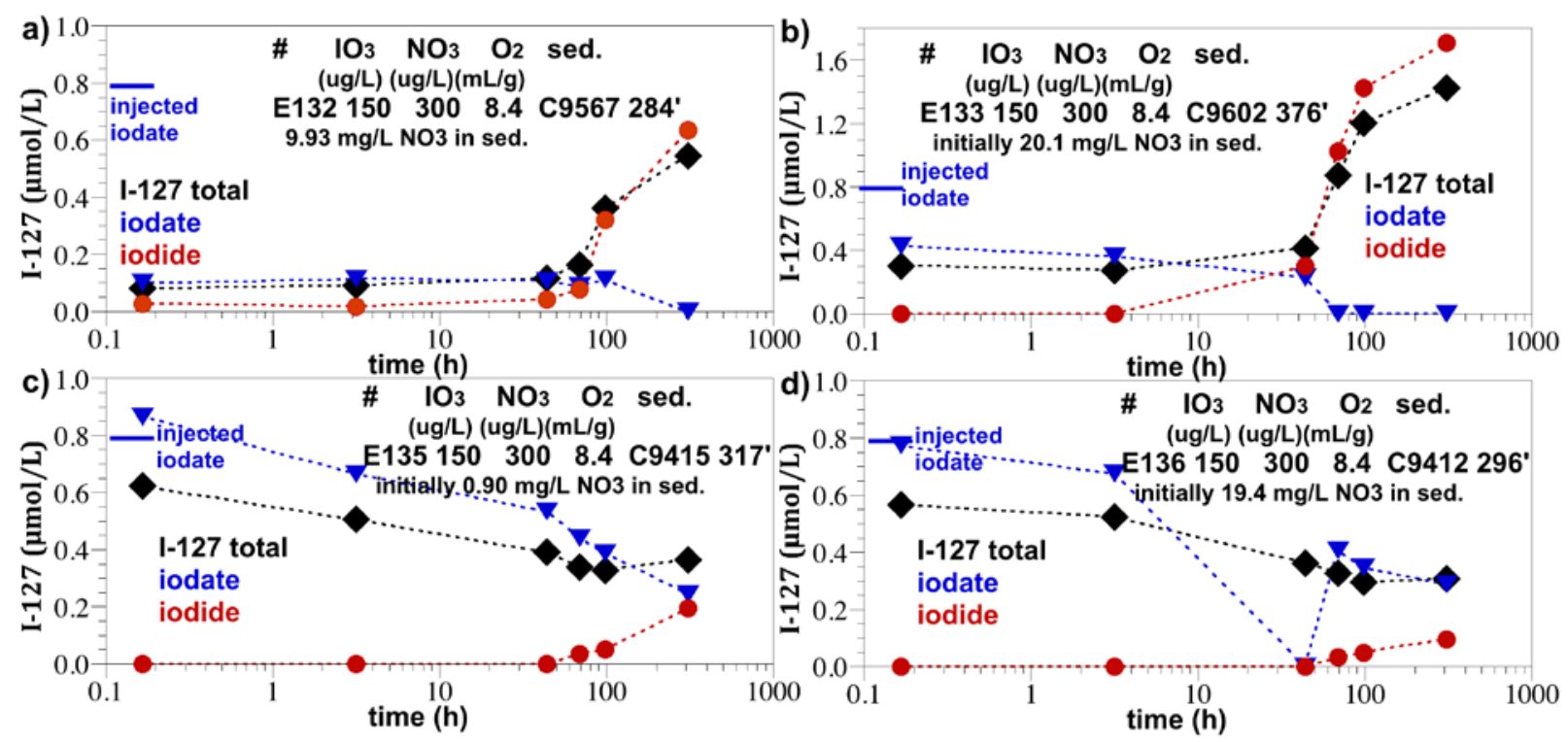

Figure 7. Coupled iodate and reduction (abiotic/biotic) in contact with UP-1 aquifer sediments in 1-D stop-flow columns, showing I-127 in experiments: a) E132, b) E133, c) E135, and d) E136. Borehole and depth written on each figure. 
Finally, redox cycling experiments with one core (C9412 295.4-295.9') are underway with three stop-flow column experiments and three solution stability (i.e., no sediment) experiments. The three stop-flow column experiments were injected with the 20 pore volumes of a) $150 \mu \mathrm{g} / \mathrm{L}$ iodate and $150 \mu \mathrm{g} / \mathrm{L}$ iodide; b) $150 \mu \mathrm{g} / \mathrm{L}$ iodate, $150 \mu \mathrm{g} / \mathrm{L}$ iodide, and $1.0 \mathrm{mg} / \mathrm{L}$ nitrate; and c) $150 \mu \mathrm{g} / \mathrm{L}$ iodate, $150 \mu \mathrm{g} / \mathrm{L}$ iodide, $1.0 \mathrm{mg} / \mathrm{L}$ nitrate, and $1.0 \mathrm{mg} / \mathrm{L}$ nitrite into a sediment column. During the 20 pore volume injection of solutions, nitrate and nitrite were observed eluting from the columns (Figure 8a, b). Results show nitrate degradation, and an increase in nitrite and ammonia (Figure 8c and d). The ammonia may also be residual ammonia from reduction of nitrate in the field-contaminated sediment (at $65 \mu \mathrm{mol} / \mathrm{L})$.
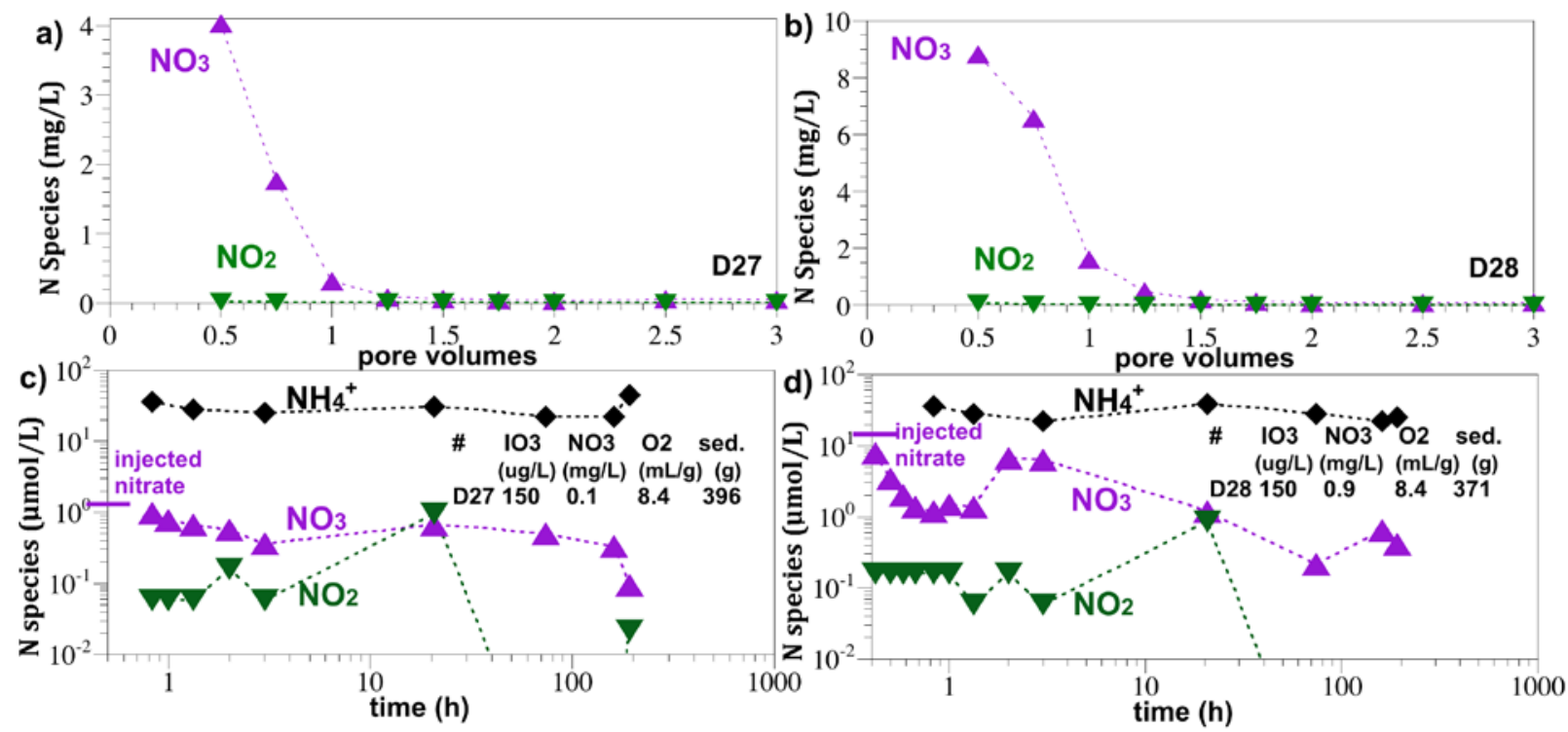

Figure 8. Coupled iodate and reduction (abiotic/biotic) in contact with vadose zone sediments showing: a) $\mathrm{N}$-species during 20 pore volume injection of $0.1 \mathrm{mg} / \mathrm{L}$ nitrate, b) $\mathrm{N}$-species during 20 pore volume injection of $1.0 \mathrm{mg} / \mathrm{L}$ nitrate and $1.0 \mathrm{mg} / \mathrm{L}$ nitrite, c) $\mathrm{N}$-species transformation over time initially with only nitrate, and d) N-species transformation over time initially with nitrate and nitrite.

Three separate batch experiments contained only these three solutions (Table 1, experiments D29 to D31) confirmed aqueous stability in contact with no microbes or mineral surfaces. It is hypothesized that nitrite may reduce iodate in the presence of microbes or specific mineral phases.

\subsection{2 lodide Oxidation}

Iodide oxidation by abiotic and/or biotic (i.e., microbes associated with the sediment) processes under anaerobic and aerobic conditions was quantified to 1800 hours (Table 1). These experiments showed no oxidation of iodide (Figure 9a and b) at a low sediment/water ratio or a high sediment/water ratio (Figure 9c). One additional iodide oxidation experiment was conducted in $2 \%$ gluteraldehyde treated sediment to decrease microbial activity. This sediment was treated for 7 days with gluteraldehyde before iodide (with gluteraldehyde) was injected into the sediment column. Because there was no abiotic or biotic iodide oxidation in the untreated sediment, this gluteraldehyde-treated sediment experiment showed the same result: no iodide oxidation (Figure 9d). Finally, iodide and peroxide were added to a peroxide-treated 
sediment column. The purpose of this sediment treatment was to oxidize any reduced iron phases and decrease microbial activity. With aqueous peroxide present, the $100 \mu \mathrm{g} / \mathrm{L}$ iodide was completely oxidized by 24 hours (Figure 9e). While this experiment has little applicability to the Hanford subsurface environment, the use of a strong oxidant such as peroxide is useful in laboratory studies for oxidizing I-125 radiolabeled iodide (as radiolabeled iodate is not available).
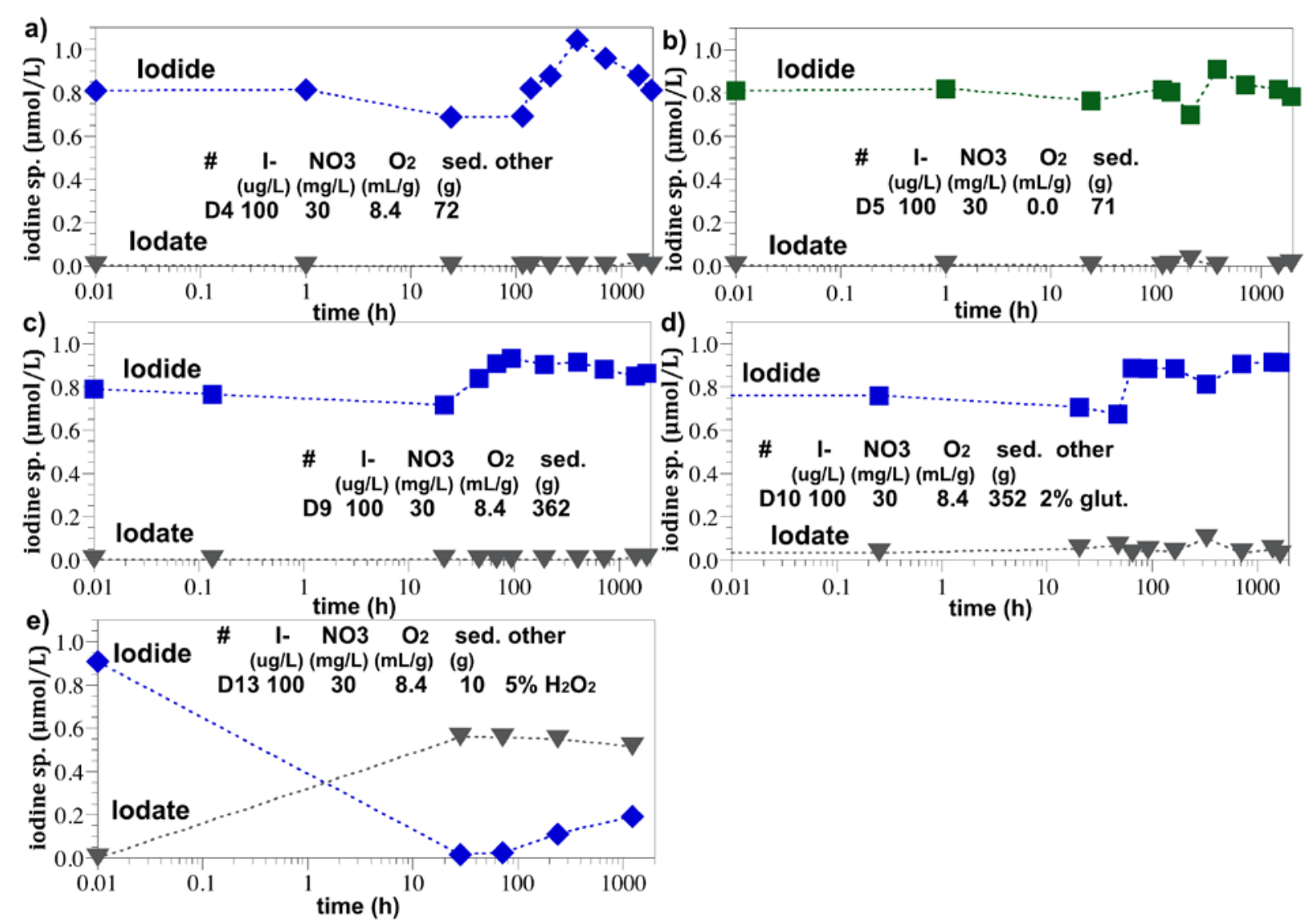

Figure 9. Iodide stability in sediments with a) oxic water, low sediment/water ratio; b) anaerobic water, low sediment/water ratio; c) oxic water, high sediment/water ratio; d) oxic water, high sediment/water ratio with $2 \%$ gluteraldehyde (and sediment pretreatment); and e) oxic water with peroxide pretreatment of the sediment. (Data from Truex et al. 2016)

\subsection{Iodine and Uranium Incorporation into Calcite}

Results of the first three tests (containing variable concentrations of $U$ and I, Table 5) showed that the co-presence of these two contaminants had little to no effect on the removal of iodate via calcite precipitation. In all experiments, approximately 50-60\% of the iodine was removed from solution, regardless of the initial U or I concentrations (Figure 10A and B). The results indicated a solid phase concentration of $4-5 \mu \mathrm{g} / \mathrm{g}$ ( $\mu \mathrm{g}$ iodine per g of calcite) in the 50-ppb iodine experiments that ended after 28 days and 7-8 $\mu \mathrm{g} / \mathrm{g}$ in the 50-ppb I experiments that ended after 60 days (Table 5). Less calcite was recovered in the 60-day experiments, and may be the cause of the difference in solid phase concentrations. All of the experiments with an initial iodine concentration of $500 \mathrm{ppb}$ iodine continued for 60 days, and all have comparable solid phase concentrations of 78-93 $\mu \mathrm{g} / \mathrm{g}$ (Table 5). Previous 
experiments conducted using the same $0.1 \mathrm{M}$ solutions resulting in solid phase concentrations of 5.7-6.8 $\mu \mathrm{g} / \mathrm{g}$ for $50 \mathrm{ppb}$ initial I concentrations (Truex et al. 2017a). With similar results across the experiments here as well as the previously conducted iodine-calcite experiments (Truex et al. 2017b), it is unlikely that the concentrations of $U$ used in these experiments had any effect (either beneficial or detrimental) on the removal of iodine by calcite precipitation.

In all tests containing uranium, the initial 4-hour sample had low U concentrations. Regardless of the initial U concentration, the first sample, taken after 4 hours, contained little $\mathrm{U}$, and showed approximately 80-90\% U removal based on the initial concentration (Figure 10c and d). However, after the 4-hour sample, the $\mathrm{U}$ is again present in solution and results indicate a much lower $\mathrm{U}$ removal percentage that fluctuates in all tests from around 0-17\% (Figure 10c and d). In both the final solution concentration and the solid $(\mu \mathrm{g} / \mathrm{g})$ concentrations, it appears the $\mathrm{U}$ is affected by the amount of iodine in the system. This was clear in Test 3, which contained $1000 \mathrm{ppb} U$ and 0-500 ppb I. When looking at the final concentrations in terms of $\mu \mathrm{g} / \mathrm{g}$, the results showed that $8.5 \%, 9.8 \%$, and $11.9 \%$ of the $\mathrm{U}$ was removed from solution in the tests containing 0,50 , and $500 \mathrm{ppb}$, respectively. The final $\mu \mathrm{g} / \mathrm{g}$ concentrations for these same tests were approximately 35.8, 36.3, and $49.2 \mu \mathrm{g} / \mathrm{g}$ for the tests that contained 0 , 50 , and 500 ppb I, respectively (Table 5).

Each experimental setup included a replicate and two controls. The controls contained the calcite forming solutions, $0.1 \mathrm{M} \mathrm{CaCl}_{2}$ and $0.1 \mathrm{M}\left(\mathrm{NH}_{4}\right)_{2} \mathrm{CO}_{3}$. Iodine concentrations in both controls and uranium concentrations in the $\left(\mathrm{NH}_{4}\right)_{2} \mathrm{CO}_{3}$ controls remaining close to the targeted initial concentrations throughout the tests. The $\mathrm{U}$ concentration in the $\mathrm{CaCl}_{2}$ control, however, was consistently $40-85 \%$ lower than expected. At the conclusion of the test, the contents of the bottles were filtered through $0.45-\mu m$ vacuum filters, but no solids could be found on the filter paper. The $\mathrm{U}$ concentration in the 4-hour samples was also low, and may be because the $\mathrm{U}$ spike was initially added into $\mathrm{CaCl}_{2}$ prior to adding the $\left(\mathrm{NH}_{4}\right)_{2} \mathrm{CO}_{3}$ to initiate calcite formation; further investigation into the low $\mathrm{U}$ concentration in the $\mathrm{CaCl}_{2}$ controls and the 4-hour samples is needed. 

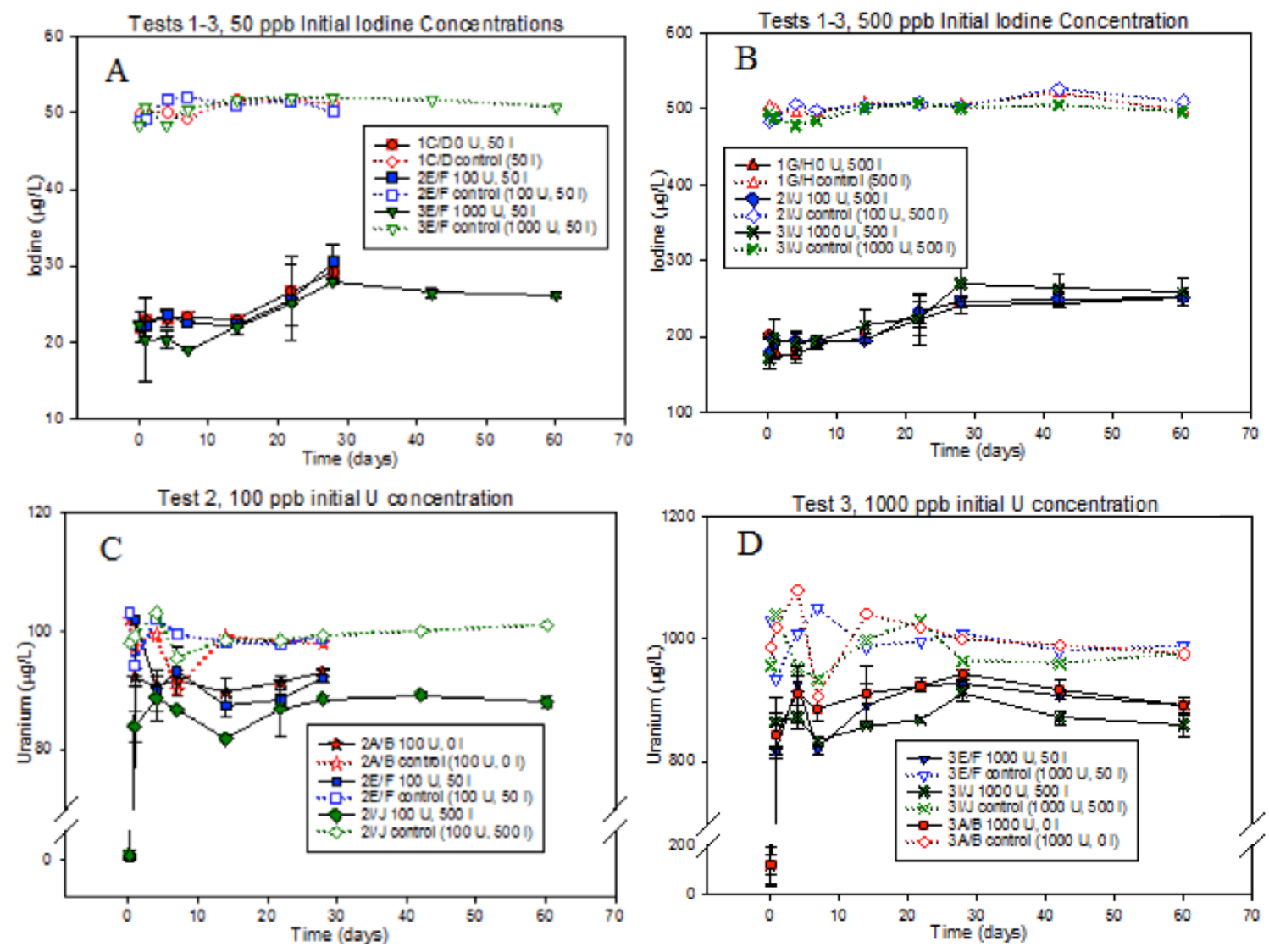

Figure 10. Iodine (A and B) and uranium (C and D) concentrations over time in calcite precipitation batch experiments with variable initial I and U concentrations: A) initial I concentrations of $50 \mathrm{ppb}$; B) initial I concentrations of $500 \mathrm{ppb}$; C) initial U concentrations of $100 \mathrm{ppb}$; D) initial U concentrations of $1000 \mathrm{ppb}$. The legend in each graph indicates concentrations of both I and U in parenthesis next to each test ID.

Table 5. Final $U$ and I concentrations associated with the calcite solid, in $\mu \mathrm{g} / \mathrm{g}$ for Tests 1-3.

\begin{tabular}{lcc} 
Sample ID & Final U $(\mu \mathrm{g} / \mathrm{g})$ & Final I $(\mu \mathrm{g} / \mathrm{g})$ \\
\hline 1A-0 U-0 I & - & - \\
1B-0 U-0 I & - & - \\
1C-0 U-50 I & - & 4.84 \\
1D-0 U-50 I & - & 4.96 \\
1G-0 U-500 I & - & 89.5 \\
1H-0 U-500 I & - & 84.6 \\
\hline 2A-100 U-0 I & 1.51 & - \\
2B-100 U-0 I & 1.79 & - \\
2E-100 U-50 I & 2.03 & 4.36 \\
2F-100 U-50 I & 1.72 & 4.79 \\
2I-100 U-500 I & 4.33 & 83.4 \\
2J-100 U-500 I & 3.88 & 86.5 \\
\hline 3A-1000 U-0 I & 35.8 & - \\
3B-1000 U-0 I & 35.7 & - \\
3E-1000 U-50 I & 39.0 & 7.78 \\
3F-1000 U-50 I & 33.7 & 8.28 \\
3I-1000 U-500 I & 52.5 & 78.3 \\
3J-1000 U-500 I & 45.9 & 92.5 \\
\hline
\end{tabular}


An additional batch experiment, Test 4, was conducted to determine the amount of $U$ and I that was being removed through adsorption onto the calcite surface versus the amount incorporated into the calcite structure. One or both of the spikes (U and/or I) were added one day after calcite precipitation began. When added late, the amount of $U$ or I removed from solution is assumed to be adsorbing to the calcite surface. The difference in the amount removed when spiked before calcite precipitation occurred and the amount removed when spiked after precipitation should approximately represent the amount being incorporated into the calcite. Results of these experiments indicated that much of the iodine, as seen in previous tests (Truex et al. 2017b), was only removed when present at the time of calcite precipitation, indicating that much of the iodine was being incorporated into the calcite structure. Test $4 \mathrm{I} / \mathrm{J}$ was the only "late spike" test that had iodine spiked prior to calcite precipitation (Figure 11). In this test, $\sim 60 \%$ of the spiked iodine was removed from solution [compared to the $\left(\mathrm{NH}_{4}\right)_{2} \mathrm{CO}_{3}$ control] and the iodine concentration remained fairly stable. In the other tests, approximately $20 \%$ was removed from solution in the first week after adding the late spike, but nearly all of the iodine returned to solution after that, indicating only a small amount of the iodate removed by calcite is from adsorption onto the calcite surface in these experiments.

Differences between the U spiked before or after precipitation were not as obvious. The U concentration in solution was inconsistent, as seen in Tests 1-3, but when added as a late spike (i.e., after calcite precipitation), slightly less $U$ was removed from solution. The three experiments in Test 4 with $U$ added as a "late spike" averaged around $2 \% \mathrm{U}$ removed compared to the $\left(\mathrm{NH}_{4}\right)_{2} \mathrm{CO}_{3}$ control. In the Test 4 experiment with $\mathrm{U}$ added prior to calcite precipitation, an average of around $7 \% \mathrm{U}$ was removed from solution throughout the test (Figure 11). An additional comparison can be made between Tests 3A/B and 4A/B. Each had zero I and an initial concentration of $1000 \mathrm{ppb} \mathrm{U}$, but in $4 \mathrm{~A} / \mathrm{B}$, the $\mathrm{U}$ spike was added late. Figure 12 shows the difference between these two experiments; $4 \mathrm{~A} / \mathrm{B}$ averaged around $7 \% \mathrm{U}$ removed while $3 \mathrm{~A} / \mathrm{B}$ averaged around $10 \% \mathrm{U}$ removed from solution. As with the iodate data, these tests indicate that $\mathrm{U}$ is also incorporated into the calcite structure, but it seems that for $\mathrm{U}$, the adsorption onto the surface may be more significant for removal via calcite compared to the iodate adsorption on calcite. 

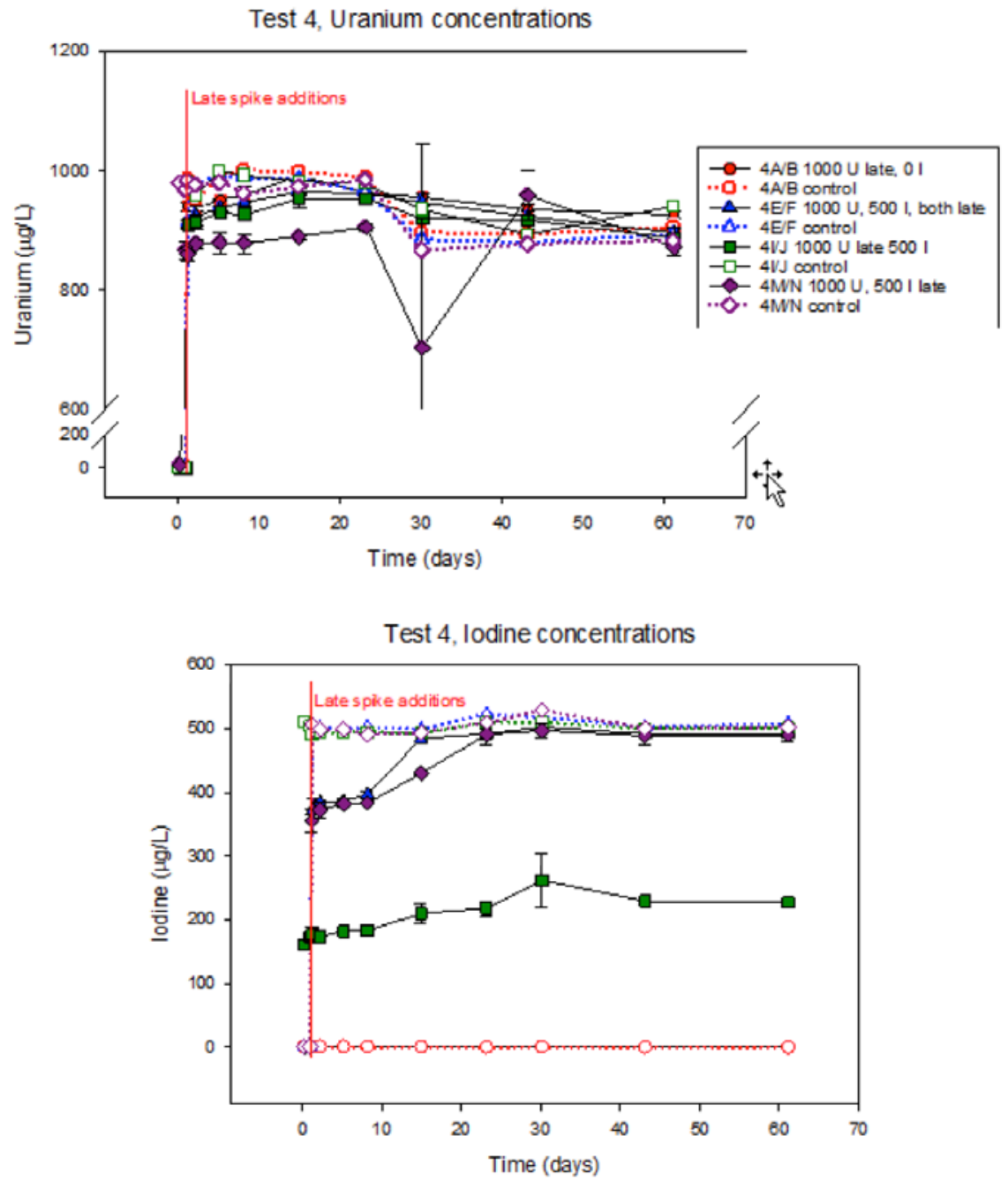

Figure 11. U (top) and I (bottom) concentrations for the "late spike" tests. Spikes that were added late (i.e., after calcite precipitation) are indicated in the legend. 


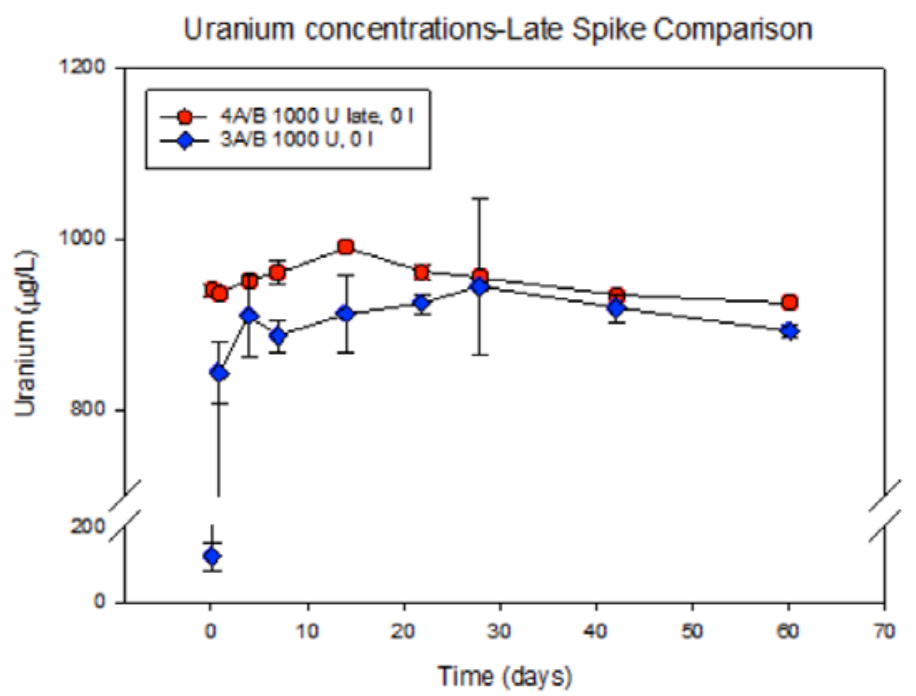

Figure 12. Comparison between tests with $1000 \mathrm{ppb}$ U initial concentrations; one was spiked prior to calcite precipitation (circles) and one was spiked after precipitation (late spike, diamonds).

\section{3 lodine Species Microbial Reactivity in the Presence of Nitrate}

Batch microcosm experiments (described in Section 3.3) were performed to study the effect of nitrate on iodate reduction by $S$. oneidensis MR-1, a known iodate reducing bacterium, and a consortium that was enriched from Hanford sediment. Experiments were run in the presence and absence of Ringold sediments, which represents an attachment surface, as well as an additional electron acceptor (Fe(III) on the mineral surface) for growth.

\subsubsection{Microbial Growth}

Seed cultures of $S$. oneidensis and the enrichment culture were grown and harvested, and experiments initially had cell densities of approximately $1 \times 10^{7}$ cells $/ \mathrm{mL}$, equating to protein levels of approximately 3 and $2.5 \mu \mathrm{g}$ protein/L, respectively. Protein concentrations for the different enrichments and associated controls showed interesting growth trends (Figure 13). Concentrations of proteins in the S. oneidensis microcosms decreased regardless of whether sediment was present in the growth environment; however, cell density stabilized in the microcosms without sediment, while when the Ringold sediments were present, cell density dropped and remained low. In contrast, protein concentration in the enrichment culture microcosm without sediment increased initially, and then dropped to near initial concentrations. Protein concentrations in the experiment with sediments dropped initially and then remained stable until the end of the experiment, when protein concentrations returned to close to initial levels. One other general observation noted in related to growth was that the enrichment culture required extended time for growth, while $S$. oneidensis grew quickly. 

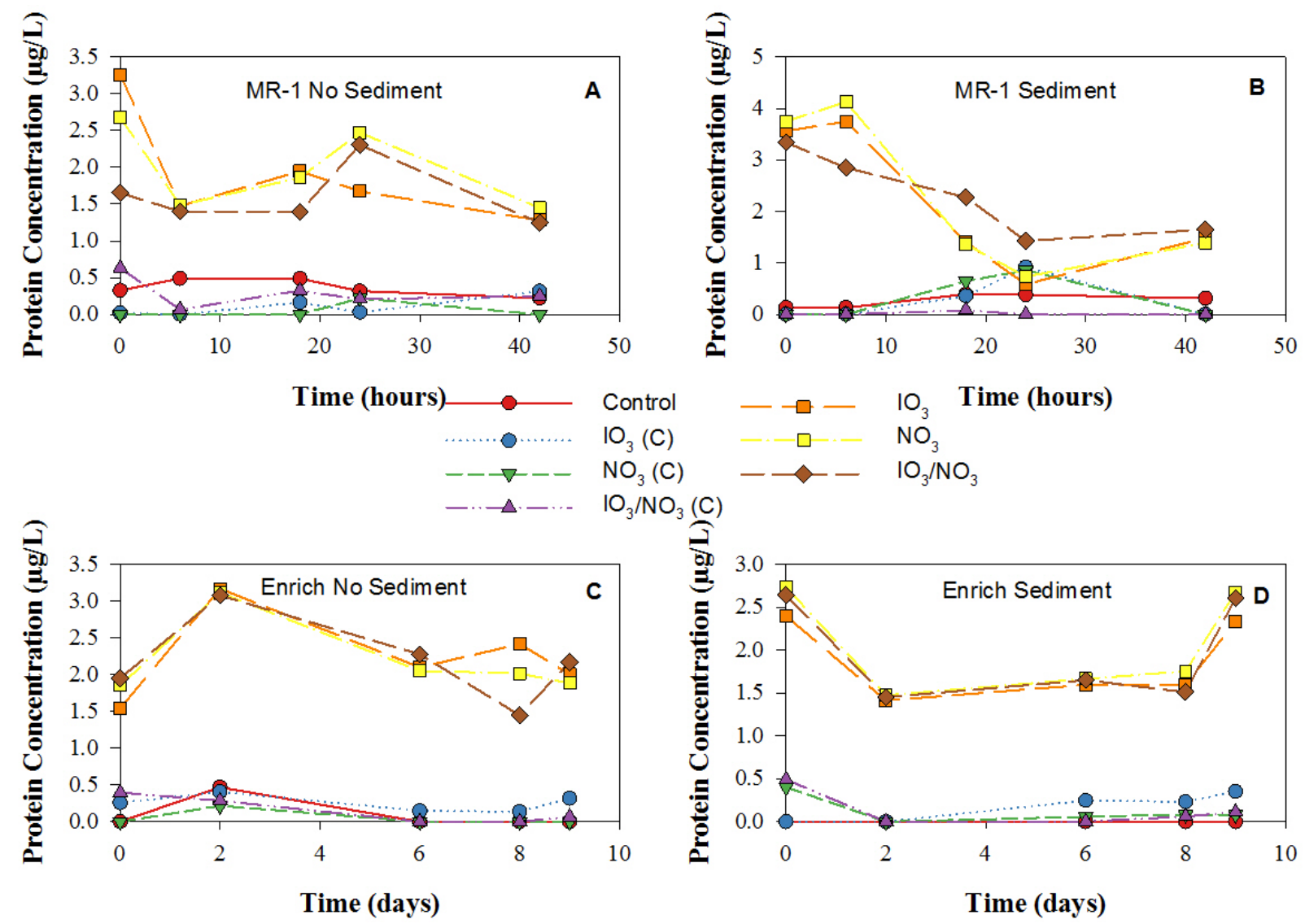

Figure 13. Protein concentration in microcosms studies over time: A) S. oneidensis MR-1 without sediment; B) S. oneidensis MR-1 with sediment; C) Hanford enrichment without sediment; D) Hanford enrichment with sediment. (Note: S. oneidensis timescale is hours, while enrichment is in days.)

\subsubsection{Carbon Metabolism}

Lactate was used as the carbon source for growth and the electron source for contaminant reduction in both the $S$. oneidensis and the enrichment microcosm experiments. Lactate was only partially consumed by microbial processes in either experiment, but there was measurable conversion to acetate during both experiments. S. oneidensis produced acetate at different times depending on whether iodate or iodate/nitrate was the sole electron acceptor (Figure 14). Interestingly, conversion of lactate to acetate only occurred in experiments where iodate was present. Creation of lactate is not likely related to the 
physiology of $S$. oneidensis and lactate concentrations reverting back to levels equal to control is likely an artifact from overlapping peaks during analysis using ion chromatography.

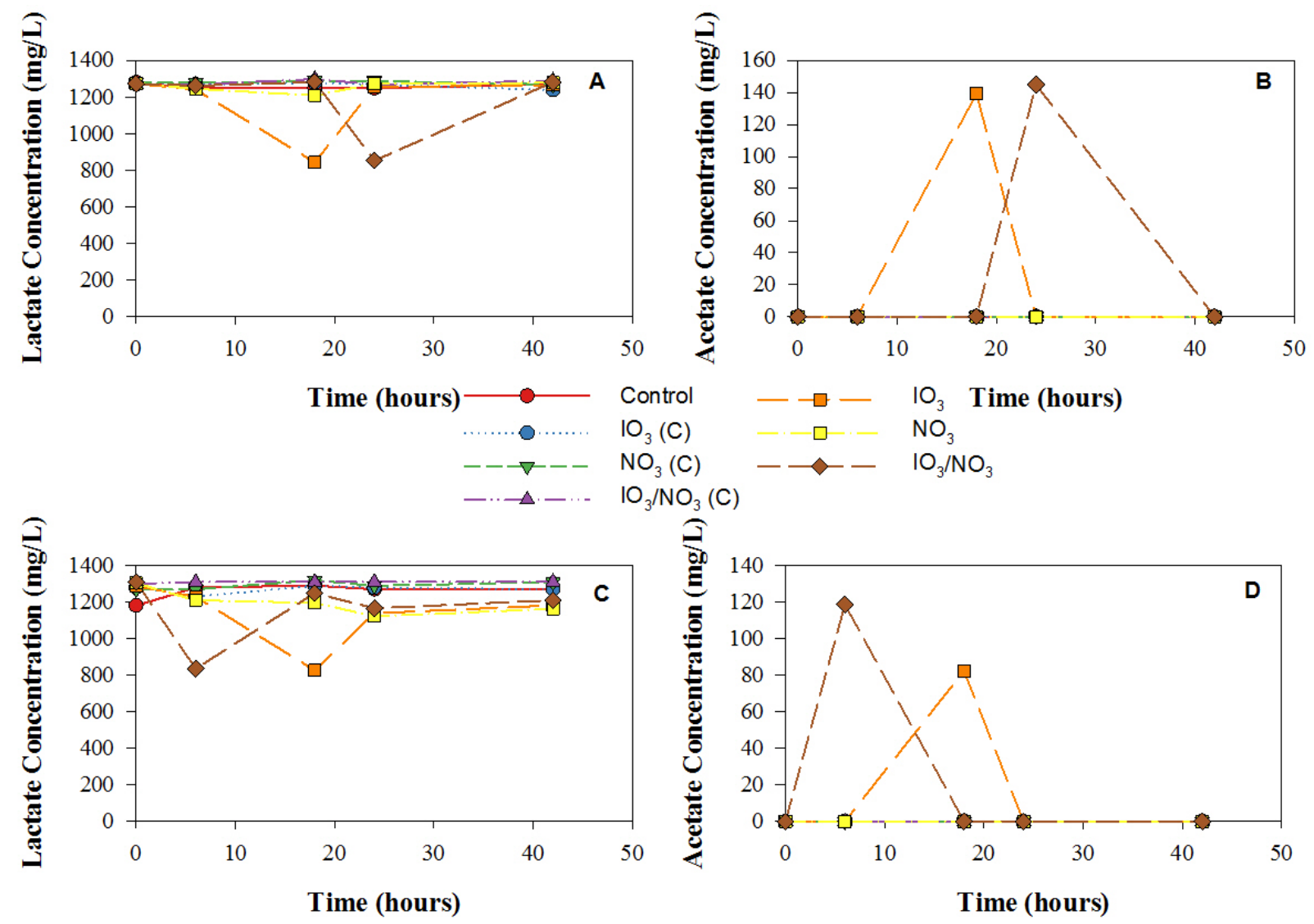

Figure 14. Lactate metabolism in microcosm experiments in which S. oneidensis MR-1 was tested for iodate and nitrate biotransformation: A) lactate concentration without sediment, B) acetate concentration without sediment; C) lactate concentration with sediment;

D) acetate concentration with sediment.

Likewise, lactate metabolism by the enrichment culture showed conversion to acetate, but only in the microcosm with sediment (Figure 15). There was slight lactate removal in the microcosm with iodate, but no acetate production was noted. When the sediment was present, lactate conversion to acetate occurred in all of the microcosms containing the enrichment. In contrast to the $S$. oneidensis microcosms, acetate did not appear to be further metabolized.

Complete conversion of lactate conversion to $\mathrm{CO}_{2}$ was likely in both the $S$. oneidensis and enrichment microcosms, since acetate concentrations in solution were less than the total amount of lactate being converted. 

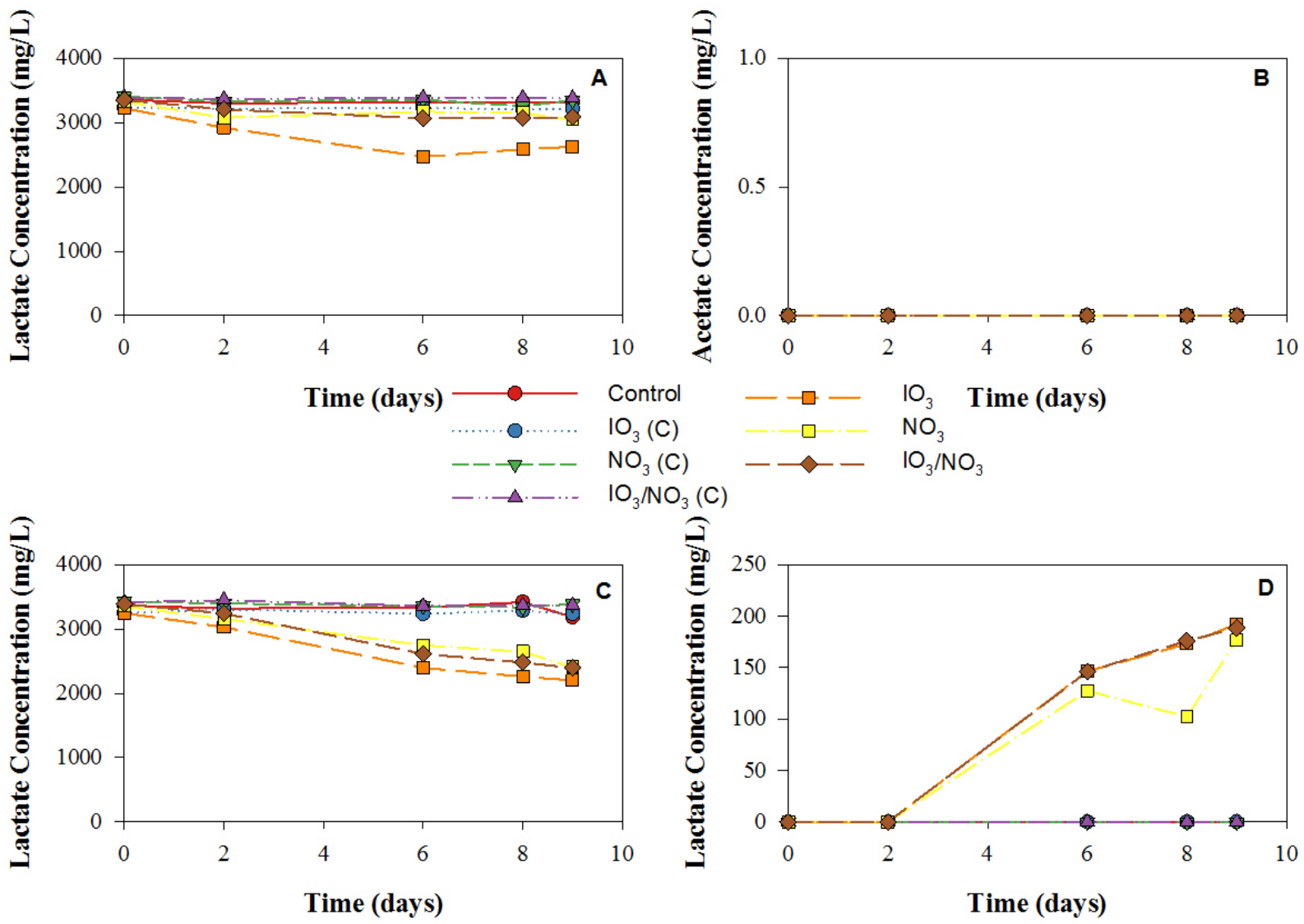

Time (days)

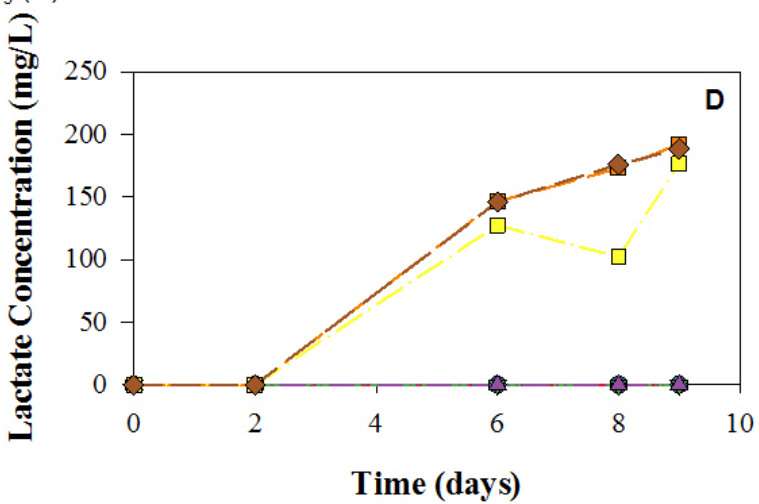

Figure 15. Lactate metabolism in microcosm experiments in which a Hanford enrichment culture was tested for iodate and nitrate biotransformation: A) lactate concentration without sediment; B) acetate concentration without sediment; C) lactate concentration with sediment; D) acetate concentration with sediment.

\subsubsection{Contaminant Transformation}

Nitrate was quickly metabolized in microcosm experiments containing Ringold sediments (Figure 16). In the $S$. oneidensis experiments, nitrate concentrations were below detection limits $(0.05 \mathrm{mg} / \mathrm{L})$, while in the enrichment experiments, nitrate was depleted within 1 day. Analytical results for nitrate in the microcosm experiments without Ringold sediment showed no detectable nitrate in any of the replicates.

While bacterial attachment to the sediment in both microcosms was apparent by the protein results in Figure 13, only low part per billion concentrations of ferrous iron were noted in the culture supernatant (data not shown). While it is likely that the bacteria reduced the ferric iron, low aqueous ferrous iron is likely due to high ferrous iron adsorption to sediment and microbial surfaces. 

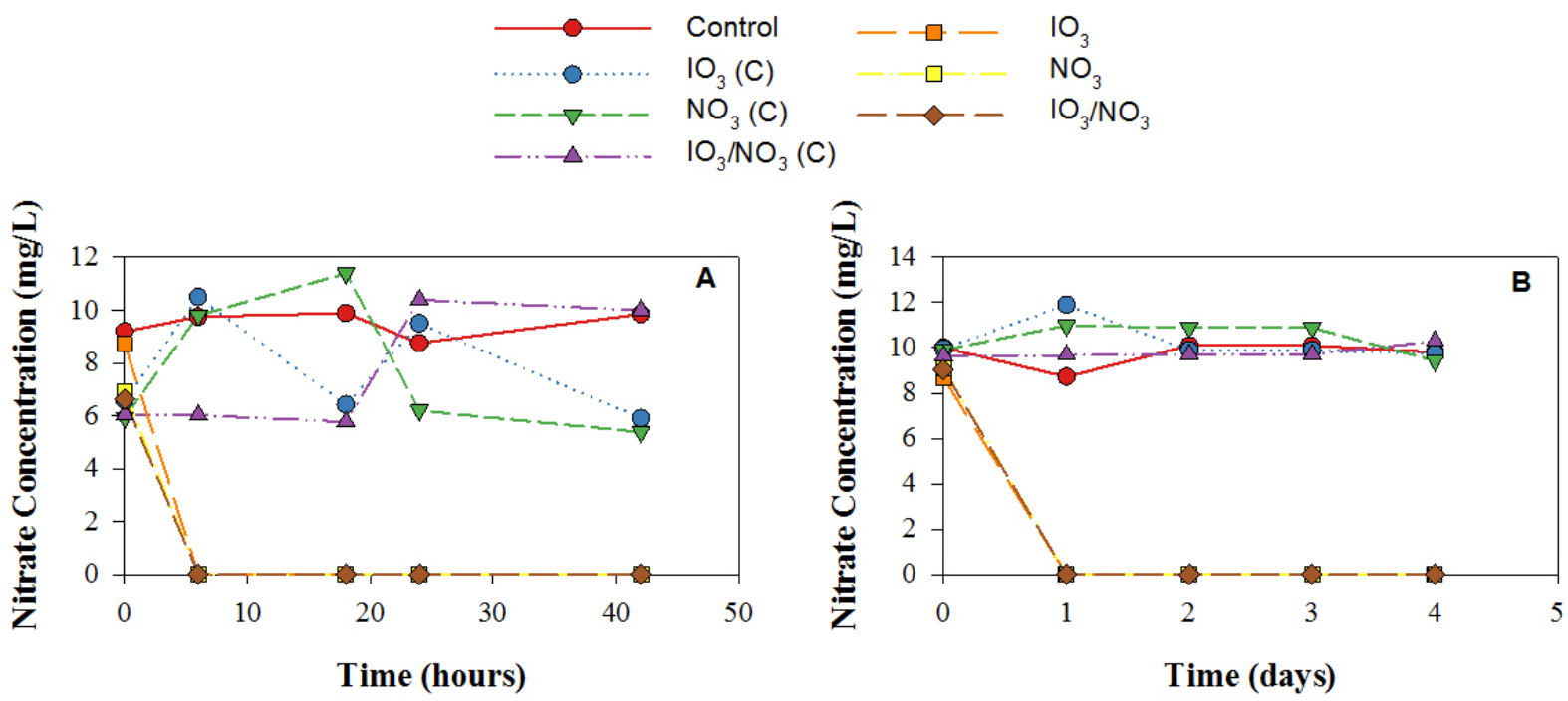

Figure 16. Nitrate transformation in microcosm experiments: A) S. oneidensis with Ringold sediments; B) Hanford enrichment culture with Ringold sediments. 


\subsection{Discussion}

\subsection{Iodine Species-Sediment Interactions with Co-Contaminants}

\subsubsection{Influence of Co-Contaminants on lodate Reduction in Sediments}

Iodate reduction was observed in different sediments under anoxic and oxic geochemical conditions (Table 6; data from this study and Truex et al. 2016). In the same aquifer sediment, the iodate reduction rate with no $\mathrm{O}_{2}$ or $\mathrm{NO}_{3}$ present was $13.2 \mathrm{pmol} \mathrm{h}^{-1} \mathrm{~g}^{-1}$, which decreased to $4.95 \mathrm{pmol} \mathrm{h}^{-1} \mathrm{~g}^{-1}$ with $8.4 \mathrm{mg} / \mathrm{L} \mathrm{O}_{2}$, and 3.64 to $7.08 \mathrm{pmol} \mathrm{h}^{-1} \mathrm{~g}^{-1}$ with $8.4 \mathrm{mg} / \mathrm{L} \mathrm{O}_{2}$ and $27 \mathrm{mg} / \mathrm{L} \mathrm{NO}_{3}$. Therefore, under high sediment/water conditions, the presence of nitrate did not increase the observed abiotic/biotic iodate reduction rate, implying that any increase in the cometabolic bioreduction rate of nitrate and iodate was a small contribution. The same sediment pretreated with $2 \%$ gluteraldehyde for 7 days (to decrease microbial activity) had an iodate reduction rate of $1.47 \mathrm{pmol} \mathrm{h}^{-1} \mathrm{~g}^{-1}$, or 9 times slower than the untreated sediment, which implies some contribution of microbial reduction of iodate. Finally, a sediment treated with peroxide (to oxidize reduced iron and manganese phases, as well as decrease microbial activity) had an iodate reduction rate of $0.89 \mathrm{pmol} \mathrm{h}^{-1} \mathrm{~g}^{-1}$, or 15 times slower than no treatment, implying abiotic processes controlled most of the observed iodate reduction in the sediment. Six vadose zone sediments showed iodate reduction (average $4.02 \pm 5.02 \mathrm{pmol} \mathrm{h}^{-1} \mathrm{~g}^{-1}$ ), which varied about two orders of magnitude from 0.06 to $23 \mathrm{pmol} \mathrm{h}^{-1} \mathrm{~g}^{-1}$, indicating that abiotic/biotic reduction in sediments varies significantly in subsurface sediments. Natural mafic minerals (fayalite, biotite, magnetite, maghemite) in Hanford vadose zone 200 Area sediments have previously been shown to reduce Tc-99 at a similar rate (Szecsody et al. 2014). Hanford sediments have also been reported to reduce chromate (Ginder-Vogel et al. 2005), uranium (VI) (Zachara et al. 2007a), and Pu (Zachara et al. 2007b), primarily from ferrous iron in illite and in iron oxides (Dong et al. 2003).

Table 6. Iodate and nitrate reduction rates measured in sediments.

\begin{tabular}{|c|c|c|c|c|c|c|c|c|}
\hline \# & sediment & $\begin{array}{l}\text { sed. } \\
\text { (g) }\end{array}$ & $\begin{array}{l}\text { iodate } \\
\text { (ug/L) }\end{array}$ & $\begin{array}{l}\text { nitrate } \\
(\mathrm{mg} / \mathrm{L})\end{array}$ & $\begin{array}{c}\mathrm{O}_{2} \\
(\mathrm{mg} / \mathrm{L})\end{array}$ & $\begin{array}{c}\text { iodate } \\
\text { reduction rate } \\
(\mathrm{pmol} / \mathrm{g} / \mathrm{h})\end{array}$ & $\begin{array}{c}\text { nitrate } \\
\text { reduction rate } \\
(\mathrm{pmol} / \mathrm{g} / \mathrm{h})\end{array}$ & other \\
\hline$\overline{\mathrm{D} 3}$ & C9483, 387-388' & 10 & 100 & 27 & 8.4 & 2.70 & & to $46.3 \mathrm{~h}$ \\
\hline D6 & C9483, 387-388' & 35 & 100 & 27 & 8.4 & 7.08 & & to $1700 \mathrm{~h}$ \\
\hline D7 & C9483, 387-388' & 35 & 100 & 27 & 0.0 & 4.95 & & to $1800 \mathrm{~h}$ \\
\hline D8 & C9483, 387-388' & 350 & 100 & 27 & 8.4 & 3.64 & & to $1800 \mathrm{~h}$ \\
\hline D16 & C9483, 387-388' & 334 & 100 & 0.0 & 0.0 & 13.2 & & to $1200 \mathrm{~h}$ \\
\hline D11 & C9483, 387-388' & 355 & 100 & 27 & 0.0 & 1.47 & & $2 \%$ glut., $1500 \mathrm{~h}$ \\
\hline D15 & C9483, 387-388' & 10 & 100 & 0.0 & 0.0 & 0.89 & & $5 \% \mathrm{H}_{2} \mathrm{O}_{2}, 1100 \mathrm{~h}$ \\
\hline E31 & C9552 104-105' & 389 & 74 & 0.0 & 0.0 & 1.04 & & 100 ug/L uranium \\
\hline E32 & C9552 134-135' & 399 & 74 & 0.0 & 0.0 & 0.059 & & $100 \mathrm{ug} / \mathrm{L}$ uranium \\
\hline E33 & C9552 194-195' & 430 & 74 & 0.0 & 0.0 & 2.28 & & 100 ug/L uranium \\
\hline E34 & C9487 134-135' & 395 & 74 & 0.0 & 0.0 & 0.40 & & 100 ug/L uranium \\
\hline E35 & C9487 230-231' & 294 & 74 & 0.0 & 0.0 & 12.4 & & 100 ug/L uranium \\
\hline E17 & C9487 58.2-59.2' & 50 & 0.7 & 6.6 & 8.4 & 1.01 & & 2600 ug/L uranium \\
\hline E37 & C9487 58.2-59.2' & 191 & 74 & 0.0 & 0.0 & 12.9 & & $2600 \mathrm{ug} / \mathrm{L}$ uranium \\
\hline E36 & C9488 219-220' & 264 & 74 & 0.0 & 0.0 & 3.44 & & 100 ug/L uranium \\
\hline E38 & C9488 219-220' & 270 & 74 & 0.0 & 0.0 & 2.52 & & 100 ug/L uranium \\
\hline E132 & C9567 284-285' & 454 & 150 & 0.300 & 8.4 & 1.05 & 167 & $9.93 \mathrm{mg} / \mathrm{L} \mathrm{NO} 3$ in sed. \\
\hline E133 & C9602 376-377' & 417 & 150 & 0.300 & 8.4 & 1.78 & 4240 & $20.1 \mathrm{mg} / \mathrm{L} \mathrm{NO} 3$ in sed. \\
\hline E135 & C9415 317-318' & 419 & 150 & 0.300 & 8.4 & & 32.6 & $0.90 \mathrm{mg} / \mathrm{L} \mathrm{NO} 3$ in sed. \\
\hline E136 & C9412 296-297' & 392 & 150 & 0.300 & 8.4 & & -- & $19.4 \mathrm{mg} / \mathrm{L} \mathrm{NO} 3$ in sed. \\
\hline
\end{tabular}


These laboratory results of slow iodate reduction in all cores appear to conflict with previously reported Hanford area groundwater analysis where $85 \%$ of the total iodine mass as iodate (Xu et al. 2015), and more recent analysis also indicates most groundwater is dominated by iodate (Lee et al. 2017). However, a depth profile in one borehole showed the shallowest depth (7.6 ft below the water table) was $45 \%$ iodate $/ 55 \%$ iodide; in contrast, greater depths to $200 \mathrm{ft}$ below the water table was all iodate dominated. In contrast, vadose zone sediments collected below the B-, T-, and S-Complexes showed $\sim 70 \%$ of iodine mass was iodide, based on batch and 1-D column leaching of the iodine contamination. Iodate reduction was measured in two aquifer sediments (Table 6, E132, E133) with rates similar to vadose zone cores. It should be noted that low permeability zones in the vadose zone typically have higher water content, and given the very slow pore water migration times in the vadose zone, reduction from mafic minerals could occur. In contrast, even if similar minerals are present in the aquifer, fast groundwater flow rates preclude sufficient contact time to result in significant iodate reduction.

Given that the iodine disposal was mainly as iodide, vadose zone cores (and shallow groundwater) being dominated by iodide is consistent (given little evidence of iodide oxidation over a range of geochemical conditions). Iodate being the dominant species in groundwater suggests a process occurs in the aquifer (or oxidation by sunlight or other process during sampling) that oxidizes iodide to iodate, or laboratory studies are biased by disturbance of sediments that exposes fresh Fe(II) surfaces, increasing reduction. If this is the case, then batch experiments with continuous mixing for 1000 hours should expose fresh ferrous iron surfaces (and have a more rapid iodate reduction rate) compared to 1-D column studies, which are only disturbed during packing. Addition of $100 \mu \mathrm{g} / \mathrm{L}$ iodate (with $\mathrm{O}_{2}$ and nitrite) in one batch experiment had an iodate reduction rate of $2.70 \mathrm{pmol} \mathrm{h}^{-1} \mathrm{~g}^{-1}$, whereas the same solution in a 1-D stop-flow column experiment had an iodate reduction rate of $3.64 \mathrm{pmol} \mathrm{h}^{-1} \mathrm{~g}^{-1}$, indicating little difference caused by potentially greater exposure to fresh ferrous iron surfaces. Iodate reduction could possibly occur in the aquifer by co-contaminants such as nitrite or other redox reactive species. Iodine species redox cycling with nitrogen species is currently being investigated (Figure 8).

\subsubsection{Influence of Nitrate on lodide Oxidation in Sediments}

Iodide oxidation was investigated in sediment systems in the presence or absence of dissolved oxygen, and no oxidation was observed by 1800 hours (Table 7). All experiments were conducted in the presence of $27 \mathrm{mg} / \mathrm{L}$ nitrate, so nitrate and iodide in contact with sediments was stable. A separate aqueous stability experiment with $100 \mu \mathrm{g} / \mathrm{L}$ iodide and $30 \mathrm{mg} / \mathrm{L}$ nitrate in oxic groundwater (Table 1) was stable to 1200 hours.

Table 7. Iodide oxidation experimental results.

\begin{tabular}{lccccccc} 
\# & sediment & $\begin{array}{c}\text { sed. } \\
\text { (g) }\end{array}$ & $\begin{array}{c}\text { iodide } \\
\text { (ug/L) }\end{array}$ & $\begin{array}{c}\text { nitrate } \\
\text { (mg/L) }\end{array}$ & $\begin{array}{c}\mathbf{O}_{\mathbf{2}} \\
\text { ( } \mathbf{m g} / \mathbf{L})\end{array}$ & $\begin{array}{c}\text { oxidation } \\
\text { rate } \\
\text { (pmol/g/h) }\end{array}$ & other \\
\hline D2 & C9483, 387-388' & 10 & 100 & 27 & 8.4 & 0.0 & to $46.3 \mathrm{~h}$ \\
D4 & C9483, 387-388' & 72.3 & 100 & 27 & 8.4 & 0.0 & to $1940 \mathrm{~h}$ \\
D5 & C9483, 387-388' & 70.6 & 100 & 30 & 0.0 & 0.0 & to $1800 \mathrm{~h}$ \\
D9 & C9483, 387-388' & 362 & 100 & 30 & 8.4 & 0.0 & to $1800 \mathrm{~h}$ \\
D10 & C9483, 387-388' & 352 & 100 & 30 & 8.4 & 0.0 & 2\% glut., $1500 \mathrm{~h}$ \\
\hline
\end{tabular}




\subsection{Iodine Species Co-precipitation in Calcite with Co-contaminants}

Batch experiments were conducted to determine the effect of uranium and iodine on the removal of these co-contaminants from solution via incorporation into or adsorption onto precipitating calcite. Results from these studies have shown that presence of uranium does not have an effect on iodate removal from solution, but increasing iodate concentrations may enhance $U$ removal. In addition, in these tests and previous experiments (Truex et al. 2017b), results indicated that a significant amount of iodate would not be removed from solution if added post-calcite precipitation. "Late spike" experiments with U have also shown a difference in $U$ removal when the spike is added pre- or post-precipitation, but the effect on $\mathrm{U}$ is less pronounced, indicating that adsorption is likely the primary mechanism for $\mathrm{U}$ removal in these experiments. The difference in removal of the $U$ and I from solution during calcite precipitation suggests that the sources of these two contaminants in the subsurface are likely not the same.

If iodine and uranium are both incorporated into calcite, and calcite is slowly dissolving during leaching, then similar iodine and uranium release rate trends would be observed for each core. However, this is not observed, as cores that leached the most I-127 were not correlated with cores that leached the most U-238. While multiple studies have shown that U-238 incorporates into calcite (Zachara et al. 2007a, b; Qafoku and Icenhower 2008; Catalano et al. 2008), and a recent study indicates iodine (as iodate) also incorporates into calcite (Truex et al. 2016), it is hypothesized that this difference in leaching behavior between I-127 and U-238 from cores implies that iodine and uranium are leaching from different surface phases (i.e., iodine not from calcite dissolution).

\subsection{Iodine Species Redox Behavior with Mainly Microbial Isolates and Co-contaminants}

In experiments with a microbial isolate (Shewanella oneidensis, MR-1, initial cell density of $1 \times 10^{7}$ cells $/ \mathrm{mL}$ ) or an enrichment culture with Ringold sediments, experiments were conducted to evaluate the influence of differing nitrate concentrations on the iodate reduction rate. Although iodine data is not available, indirect measurements of microbial growth, carbon source degradation, and nitrate reduction did provide some information. Experiments with the microbial isolate metabolized nitrate within 6 hours, degraded lactate rapidly (within 10 to 30 hours), and showed some microbial growth (i.e., protein concentrations increased). In contrast, experiments with the enrichment culture of sediment microbial biomass metabolized nitrate more slowly (within 24 hours), degraded lactate more slowly (20 to 40 hours), and showed a decrease in microbial biomass (i.e., protein concentration). 


\subsection{Conclusions}

The objective of this co-mingled study is to evaluate the significance of co-contaminants on the migration and transformation of iodine species in the Hanford subsurface environment. The specific co-contaminant issues investigated through laboratory experiments are a) the amount of change of the iodate bioreduction rate due to the presence of differing nitrate concentrations, b) the change in iodate uptake mass and rate of uptake into precipitating calcite due to the presence of differing amounts of uranium, and c) whether nitrite can reduce iodate in the presence of microbes and/or minerals acting as catalysts. In addition, laboratory results are compared with recent field iodine speciation data for consistency.

Iodate reduction was observed in eight different Hanford vadose zone and aquifer sediments under anoxic and oxic geochemical conditions, averaging $4.01 \pm 5.02 \mathrm{pmol} \mathrm{h}^{-1} \mathrm{~g}^{-1}$ (range 0.06 to $13.2 \mathrm{pmol} \mathrm{h}^{-1} \mathrm{~g}^{-1}$ ). Iodate reduction decreased two-fold in the presence of $8.4 \mathrm{mg} / \mathrm{L} \mathrm{O}_{2}$ or in the presence of $8.4 \mathrm{mg} / \mathrm{L} \mathrm{O}_{2}$ and $27 \mathrm{mg} / \mathrm{L}$ nitrate. Therefore, under high sediment/water conditions in these laboratory 1-D columns, the presence of nitrate did not increase the observed abiotic/biotic iodate reduction rate. This implies that any increase in the cometabolic bioreduction rate of nitrate and iodate was a small contribution. High sediment/water conditions occur in the Hanford aquifer (i.e., field sediment microcosm with no carbon addition). Separate experiments with a microbial isolate (Shewanella oneidensis, MR-1, initial cell density of $1 \times 10^{7}$ cells $/ \mathrm{mL}$ ) or an enrichment culture with Ringold sediments designed to evaluate predominantly the microbial iodate reduction with and without nitrate were inclusive. Sediment pretreatment with $2 \%$ gluteraldehyde for 7 days (to decrease microbial activity) decreased the iodate reduction 9 times, implying some microbial contribution to the overall iodate reduction. Sediment pretreatment with 5\% peroxide (to oxidize reduced iron and manganese phases, and to decrease microbial activity) decreased the iodate reduction rate 15 times, implying abiotic processes controlled most of the observed iodate reduction in the sediment. Natural mafic minerals (fayalite, biotite, magnetite, maghemite) in Hanford vadose zone 200 Area sediments have previously been shown to abiotically reduce pertechnetate (Szecsody et al. 2014), which requires slightly more reducing conditions than iodate.

Laboratory results with a range of iodate reduction rates in different vadose zone and aquifer sediments are consistent with iodine speciation in the vadose zone, which is $\sim 70 \%$ iodide, but are inconsistent with iodine speciation in groundwater, which is nearly all iodate (Xu et al. 2015; Lee et al. 2017). However, a depth profile in one borehole has shown a predominance of iodate with shallow iodide. One hypothesis is that laboratory experiments unnaturally expose fresh ferrous iron surfaces, which then results in iodate reduction. This hypothesis is unlikely because batch experiments are conducted with continuous mixing for 1000 hours, and results in grinding sediments to a much greater extent than packing 1-D columns. Both batch and column experiments in this study showed the same iodate reduction rate with the same sediment.

Results in this study showed that iodide was stable in the presence of nitrate for 1200 hours with and without sediments, so nitrate was not reduced by iodide oxidation to iodate. Other hypotheses that could account for the difference between field and laboratory data, but are not currently being investigated, include a) collection of aquifer water in the field is oxidizing iodide (by sunlight or other mechanism), b) repacking sediment into 1-D columns or batch systems stimulated microbial activity (i.e., such as 
contamination by airborne microbes), and c) iodine species volatilization (bioconversion into methyl iodine then volatilized).

Studies of field vadose zone (Truex et al. 2017a; Szecsody et al. 2017) and aquifer cores (Lee et al. 2017) have shown that the leached iodine mass is correlated to the leaching rate, with faster initial leaching of aqueous and adsorbed iodine followed by slower leaching from the slow dissolution of carbonates (or other phases). Sequential liquid extractions of contaminants from cores show that $50 \%$ to $80 \%$ of the iodine mass in the sediment can be dissolved by the $\mathrm{pH} 5$ and $\mathrm{pH} 2.3$ acetate extractions, which dissolve carbonates and other phases such as iron oxides. If iodine and uranium are both incorporated into calcite, and calcite is slowly dissolving during leaching, then similar iodine and uranium release rate trends would be observed for each core. Since this trend was not observed in 18 cores, and multiple studies have shown that uranium incorporates into calcite (Zachara et al., 2007a, b; Qafoku and Icenhower 2008; Catalano et al. 2008), this implies that iodine is incorporated into a different surface phase.

Batch experiments conducted to quantify the coupled uranium-iodate incorporation into or adsorption onto precipitating calcite showed that presence of uranium did not influence iodate removal from solution, but increasing iodate concentrations may enhance $U$ removal. In addition, in these tests and previous experiments (Truex et al. 2017b), results indicated that a significant amount of iodate would not be removed from solution if added post-calcite precipitation. "Late spike" experiments with U have also shown a difference in $U$ removal when the spike is added pre- or post-precipitation, but the effect on $U$ is less pronounced, indicating that adsorption is likely the primary mechanism for $U$ removal in these experiments. The difference in removal of the $U$ and I from solution during calcite precipitation suggests that the sources of these two contaminants in the subsurface are likely not the same. 


\subsection{Quality Assurance}

The PNNL Quality Assurance (QA) Program is based upon the requirements as defined in DOE Order 414.1D, Quality Assurance, and 10 CFR 830, "Energy/Nuclear Safety Management, Subpart A, Quality Assurance Requirements. PNNL has chosen to implement the following consensus standards in a graded approach:

- ASME NQA-1-2000, Quality Assurance Requirements for Nuclear Facility Applications, Part 1, Requirements for Quality Assurance Programs for Nuclear Facilities.

- ASME NQA-1-2000, Part II, Subpart 2.7, Quality Assurance Requirements for Computer Software for Nuclear Facility Applications, including problem reporting and corrective action.

- ASME NQA-1-2000, Part IV, Subpart 4.2, Guidance on Graded Application of Quality Assurance (QA) for Nuclear-Related Research and Development.

The procedures necessary to implement the requirements are documented through PNNL's "How Do I...? (HDI), a system for managing the delivery of laboratory-level policies, requirements, and procedures.

The DVZ-AFRI Quality Assurance Plan (QA-DVZ-AFRI-001) was applied as the applicable QA document for this work under the NQA-1 QA program. This QA plan conforms to the QA requirements of DOE Order 414.1D and 10 CFR 830, Subpart A. This effort is subject to the Price Anderson Amendments Act.

The implementation of the Deep Vadose Zone - Applied Field Research Initiative QA program is graded in accordance with NQA-1-2000, Part IV, Subpart 4.2, Guidance on Graded Application of Quality Assurance (QA) for Nuclear-Related Research and Development.

This work was conducted under the Applied Research level to ensure the reproducibility and defensibility of these experimental results. As such, reviewed calculation packages are available upon request except where experimental information is denoted as a scoping or preliminary study.

This work used PNNL's Environmental Sciences Laboratory (ESL) for chemical analyses. The ESL operates under a dedicated QA plan that complies with the Hanford Analytical Services Quality Assurance Requirements Document (HASQARD), Rev. 3. ESL implements HASQARD through Conducting Analytical Work in Support of Regulatory Programs (CAWSRP). Data quality objectives established in CAWSRP were generated in accordance with HASQARD requirements. Chemical analyses of testing samples and materials were conducted under the ESL QA Plan.

QA reviews of data and analyses were conducted for this work in accordance with the QA plan. There were no reportable QA issues with the data included in this report. 


\subsection{References}

Catalano J, JP McKinley, JM Zachara, S Heald, SC Smith, and G Brown. 2008. "Changes in uranium speciation through a depth sequence of contaminated Hanford sediments.” Environ. Sci. Technol. 40(8):2517-2524.

Dong H, RK Kukkadapu, JK Fredrickson, JM Zachara, DW Kennedy, and HM Kostandarithes. 2003. "Microbial reduction of structural Fe(III) in illite and goethite.” Environ. Sci. Technol. 37(7):1268-1276.

Ginder-Vogel M, T Borch, MA Mayes, PM Jardine, and S Fendorf. 2005. “Chromate reduction and retention processes within arid subsurface environments.” Environ. Sci. Technol. 39(20):7833-7839.

Kaplan DI, RJ Serne, KE Parker, and IV Kutnyakov. 2000. "Iodide sorption to subsurface sediments and illitic minerals.” Environ. Sci. Technol. 34(3): 399-405.

Qafoku NP and JP Icenhower. 2008. "Interactions of aqueous U(VI) with soil minerals in slightly alkaline natural systems.” Reviews in Environmental Science and Biotechnology 7:355-380.

Research Center for Deep Geological Environments. 2005. Atlas of Eh-pH Diagrams, Intercomparison of thermodynamic data bases. Geological Survey of Japan Open File Report No 419, National Institute of Advanced Industrial Science and Technology, Naoto, Takeno, Japan.

Szecsody J, M Truex, B Lee, C Strickland, J Moran, M Snyder, C Resch, L Zhong, B Gartman, D Saunders, S Baum, I Leavy, J Horner, B Williams, B Christiansen, E McElroy, M Nims, R Clayton, and D Appriou. 2017. Geochemical, Microbial, and Physical characterization of 200-DV-1 Operable Unit B-Complex Cores from Boreholes C9552, C9487, and C9488 on the Hanford Site Central Plateau. PNNL-26266, Pacific Northwest National Laboratory, Richland, WA.

Szecsody JE, D Jansik, JP McKinley, and N Hess. 2014. “Influence of alkaline waste on technetium mobility in Hanford formation sediments.” J. Environ. Radioact.135:147-160.

Truex MJ, BD Lee, CD Johnson, NP Qafoku, JE Szecsody, JE Kyle, M Tfaily, MMV Snyder, AR Lawter, M Oostrom, G Tartakovsky, II Leavy, EM McElroy, D Appriou, R Sahajpal, MM Carroll, GV Last, MH Lee, and DI Kaplan. 2016. Conceptual Model of Iodine Behavior in the Subsurface at the Hanford Site. PNNL-24709, Rev. 1, Pacific Northwest National Laboratory, Richland, WA.

Truex M, J Szecsody, N Qafoku, C Strickland, J Moran, B Lee, M Snyder, A Lawter, C Resch, B Gartman, L Zhong, M Nims, D Saunders, B Williams, J Horner, I Leavy, S Baum, B Christiansen, R Clayton, E McElroy, D Appriou, K Tyrell, and M Striluk. 2017a. Contaminant Attenuation and Transport Characterization of 200-DV-1 Operable Unit Sediment Samples. PNNL-26208, Pacific Northwest National Laboratory, Richland, WA.

Truex MJ, BD Lee, CD Johnson, NP Qafoku, JE Szecsody, JE Kyle, MM Tfaily, MMV Snyder, AR Lawter, M Oostrom, GD Tartakovsky, II Leavy, EM McElroy, D Appriou, R Sahajpal, MM Carroll, GV Last, MH Lee, DI Kaplan, KJ Cantrell, DL Saunders, RK Chu, EA Cordova, WL Garcia, S Kerisit, O Qafoku, M Bowden, F Smith, JG Toyoda, AE Plymale. 2017b. Conceptual Model of Iodine Behavior in 
the Subsurface at the Hanford Site. PNNL-24709, Rev. 2, Pacific Northwest National Laboratory, Richland, WA.

Xu C, D Kaplan, S Zhang, M Athon, Y Ho, H Li, C Yeager, K Schwehr, R Grandbois, D Wellman, and P Santschi. 2015. "Radioiodine sorption/desorption and speciation transformation by subsurface sediments from the Hanford Site.” J. Env. Radioact. 139:43-55.

Zachara J, C Brown, J Christensen, JA Davis, E Dresel, C Liu, S Kelly, J McKinley, J Serne, and W Um. 2007a. A Site-wide Perspective on Uranium Geochemistry at the Hanford Site. PNNL-17031, Pacific Northwest National Laboratory, Richland, WA.

Zachara JM, J Serne, M Freshley, F Mann, F Anderson, M Wood, T Jones, and D Myers. 2007b. "Geochemical processes controlling migration of tank wastes in Hanford's vadose zone." Vadose Zone J. 6:985-1003. 


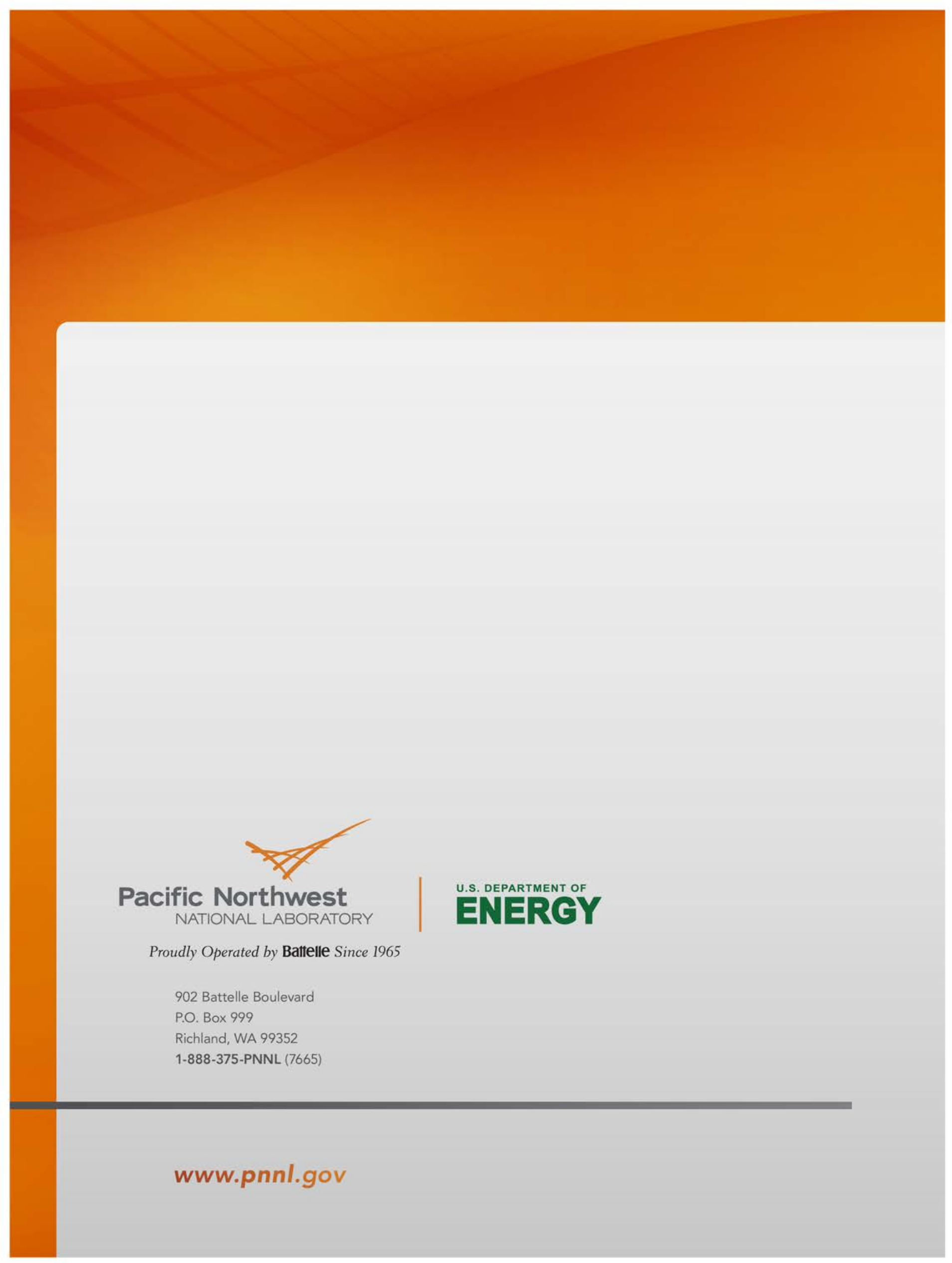

